\title{
Genetic Basis of Dual Diagnosis: A Review of Genome-Wide Association Studies (GWAS) Focusing on Patients with Mood or Anxiety Disorders and Co-Occurring Alcohol-Use Disorders
}

\author{
Kaloyan Stoychev ${ }^{1, * \mathbb{D}}$, Dancho Dilkov ${ }^{2}$, Elahe Naghavi ${ }^{3}$ and Zornitsa Kamburova ${ }^{4}$ \\ 1 Department of Psychiatry, Medical University Pleven, 5800 Pleven, Bulgaria \\ 2 Department of Psychiatry, Military Medical Academy Sofia, 1606 Sofia, Bulgaria; psihiatria@vma.bg \\ 3 Medical University Pleven, 5800 Pleven, Bulgaria; elahe.97@gmail.com \\ 4 Department of Medical Genetics, Medical University Pleven, 5800 Pleven, Bulgaria; \\ zornicakamburova@gmail.com \\ * Correspondence: kaloyan_stoichev@abv.bg; Tel.: +359-64-886-867
}

check for

updates

Citation: Stoychev, K.; Dilkov, D.; Naghavi, E.; Kamburova, Z. Genetic Basis of Dual Diagnosis: A Review of Genome-Wide Association Studies (GWAS) Focusing on Patients with Mood or Anxiety Disorders and Co-Occurring Alcohol-Use Disorders. Diagnostics 2021, 11, 1055. https:// doi.org/10.3390/diagnostics11061055

Academic Editor: Drozdstoi Stoyanov

Received: 10 May 2021

Accepted: 3 June 2021

Published: 8 June 2021

Publisher's Note: MDPI stays neutral with regard to jurisdictional claims in published maps and institutional affiliations.

Copyright: (c) 2021 by the authors. Licensee MDPI, Basel, Switzerland. This article is an open access article distributed under the terms and conditions of the Creative Commons Attribution (CC BY) license (https:/ / creativecommons.org/licenses/by/ $4.0 /)$.

\begin{abstract}
Background: Comorbidity between Alcohol Use Disorders (AUD), mood, and anxiety disorders represents a significant health burden, yet its neurobiological underpinnings are elusive. The current paper reviews all genome-wide association studies conducted in the past ten years, sampling patients with AUD and co-occurring mood or anxiety disorder(s). (2) Methods: In keeping with PRISMA guidelines, we searched EMBASE, Medline/PUBMED, and PsycINFO databases (January 2010 to December 2020), including references of enrolled studies. Study selection was based on predefined criteria and data underwent a multistep revision process. (3) Results: 15 studies were included. Some of them explored dual diagnoses phenotypes directly while others employed correlational analysis based on polygenic risk score approach. Their results support the significant overlap of genetic factors involved in AUDs and mood and anxiety disorders. Comorbidity risk seems to be conveyed by genes engaged in neuronal development, connectivity, and signaling although the precise neuronal pathways and mechanisms remain unclear. (4) Conclusion: given that genes associated with complex traits including comorbid clinical presentations are of small effect, and individually responsible for a very low proportion of the total variance, larger samples consisting of multiple refined comorbid combinations and confirmed by re-sequencing approaches will be necessary to disentangle the genetic architecture of dual diagnosis.
\end{abstract}

Keywords: mood disorders; anxiety disorders; alcohol use disorders; comorbidity; genetics; GWAS

\section{Introduction}

Alcohol use disorders (AUDs) affected >100 million people in 2016 [1], whereas, a year earlier, 322 million lived with depression and 264 million suffered from anxiety disorders [2]. In addition to being globally significant health problems in their own right, these disorders occur together much more frequently than expected by chance, confirming a phenomenon known as comorbidity or dual diagnosis which has been verified by a number of population- [3-9] and clinically [10-14] based studies over the past three decades. Generally estimated, odds ratios (OR) for the association are 1.64 and 1.53 for the combination anxiety disorder-AUD and depression-AUD respectively [15].

Co-occurring mood and anxiety disorders increase the severity of AUD and associated disability [16] whereas AUD negatively impacts anxiety and mood disorder by worsening symptoms [17], magnifying suicide risk [18], and compromising treatment efficacy [17,19]. Thus, advances in understanding the mechanisms underlying comorbidity will ultimately result in better treatment outcomes. The variety of explanation hypotheses of comorbidity [20] may be broken down to two groups [21]. According to the causal or illness-mediated theories [22], a primary alcohol, mood, or anxiety disorder directly or indirectly causes the 
secondary condition. The theories on shared etiological factors, on the other hand, assume that one or more common causal factor(s) drive the development of both disorders. While causal theories are outside the scope of this paper, common neurobiological etiology, particularly the research on the genetic basis of comorbidity, will be discussed below in detail.

In the past several decades, twin and other behavioral genetic studies have shown a substantial genetic overlap between internalizing disorders of the mood and anxiety spectrum and externalizing disorders encompassing alcohol and drug dependence [23-25]. Subsequently, a more comprehensive exploration of the genetic basis of comorbidity was provided by linkage studies [26] which examine families with multiple affected members to detect chromosomal regions with genetic risk variants [27]. In a landmark linkage mapping study on alcohol-depression comorbidity, Nurnberger et al. [28] reanalyzed dataset from the Collaborative Study on the Genetics of Alcoholism (COGA) [29,30], consisting of 1295 individuals from families affected by alcoholism, confirming a locus on chromosome 1 (near the $120 \mathrm{~cm}$ region) containing gene(s) that significantly predispose individuals to alcoholism, depression, or both. Notably, several subsequent studies [31-33] have confirmed at least two linkage regions at around 70 and $120 \mathrm{cM}$ of chromosome 1 as substantially associated with neuroticism - a personality trait intimately related to a broad array of anxiety symptoms, depression, and alcoholism [34].

Over the past 15 years, genome-wide association studies (GWAS) have become technically as well as economically affordable and as a consequence of that, they are gradually displacing linkage and other candidate gene studies in the field of psychiatric genetics [35]. GWAS entail screening hundreds of thousands to a million genomic variants (single nucleotide polymorphisms, SNPs) in a case-control design allowing for statistical calculation of each particular variant's association with the phenotype of interest expressed as an odds ratio of increased or decreased risk [36]. Initially successful with the detection of genes involved in age-related macular degeneration in 2005 [37], the GWAS design has now been broadened to numerous complex traits, including neuropsychiatric illnesses. Spotting a large number of disease-associated risk loci across the human genome for every phenotype of interest, GWAS confirm the pre-existing assumption that rather than single causal genes (according to the Mendelian pattern of inheritance), hundreds to thousands of genetic variants widely spread in the population may confer small accretions of risk for a common disease [38]. In complex genetic disorders such as mental illnesses, the GWAS approach is much more powerful in distinguishing meaningful illness-associated genetic loci as compared to the traditional twin and linkage studies discussed above. While in the most common type of GWAS sampling individuals with schizophrenia or bipolar disorder the attributable risk to each genome-wide significant SNP is small $(\mathrm{OR}<1.2)$, the accumulation of multiple risk SNPs allows for the development of the composite weighted sum of the effects of all common variants, known as the polygenic risk score (PRS) [36]. The latter might be able to aid diagnostics of psychiatric disorders in the near future [39].

Although the current large GWAS databases are focusing on single diagnoses-mostly schizophrenia [36], major depression or bipolar disorder [40], an increasing number of studies in the past 10 years have addressed dual diagnosis phenotypes with a GWAS approach. The current paper attempts to summarize and discuss the results of all the published GWAS exploring samples with alcohol misuse and anxiety or mood disorders comorbidity. In doing so, outlining some possible neurobiological mechanisms and pathways connecting both groups of disorders will be attempted.

\section{Materials and Methods}

We implemented a systematic literature review based on Preferred Reporting Items for Systematic Reviews and Meta-Analyses (PRISMA) guidelines [41].

\subsection{Search Algorithm}

\subsubsection{Inclusion Criteria}

a. Articles written in English and published in peer-reviewed journals; 
b. Studies performed in humans (animal models relevant to human findings were allowed);

c. Studies of samples with phenotypes of interest-MDD/AUD, BPD/AUD or Anxiety / Anxiety Disorder/AUD identifying the presence of SNPs with a genome-wide level of significance $\left(p<5 \times 10^{-8}\right)$ or suggestive genome-wide level of significance $\left(p<1 \times 10^{-4}\right)$;

d. Papers reporting statistically significant correlation between MDD-PRS, BPD-PRS or Anxiety/Neuroticism PRS and alcohol phenotypes-DSM-IV alcohol dependence or alcohol abuse.

\subsubsection{Exclusion Criteria}

a. Studies including alcohol phenotypes that are not based on DSM-IV/5 or ICD-10 criteria, but on screening or other tools for assessment of alcohol use instead-e.g., Alcohol Use Disorders Identification Test (AUDIT) [42].

\subsection{Data Sources and Keywords}

EMBASE, Medline/PUBMED, and PsycINFO databases were searched for a period of 10 years-from 01/01/2010 to 31/12/2020 with the following keywords:" Co-occurring disorders", "Comorbidity", "Dual Diagnosis", "Mood disorder(s)", "Major Depression (MDD)", "Bipolar Disorder", "Anxiety Disorder(s)", Alcohol Use Disorder", "Alcohol Abuse", "Alcohol Dependence" and "Genome-wide association study(ies) (GWAS)". While analyzing articles identified by this search, all papers indexed in the reference sections were explored and included in the review if eligible.

\subsection{Selection of Studies}

A total of 58 studies were detected by the initial search performed by one author (EN). After the removal of duplicates, 22 articles remained. All of them were reviewed in full text by three authors-K.S. and D.D. (psychiatrists) and Z.K. (specialist in medical genetics) to assess their final eligibility for this paper (Figure 1).

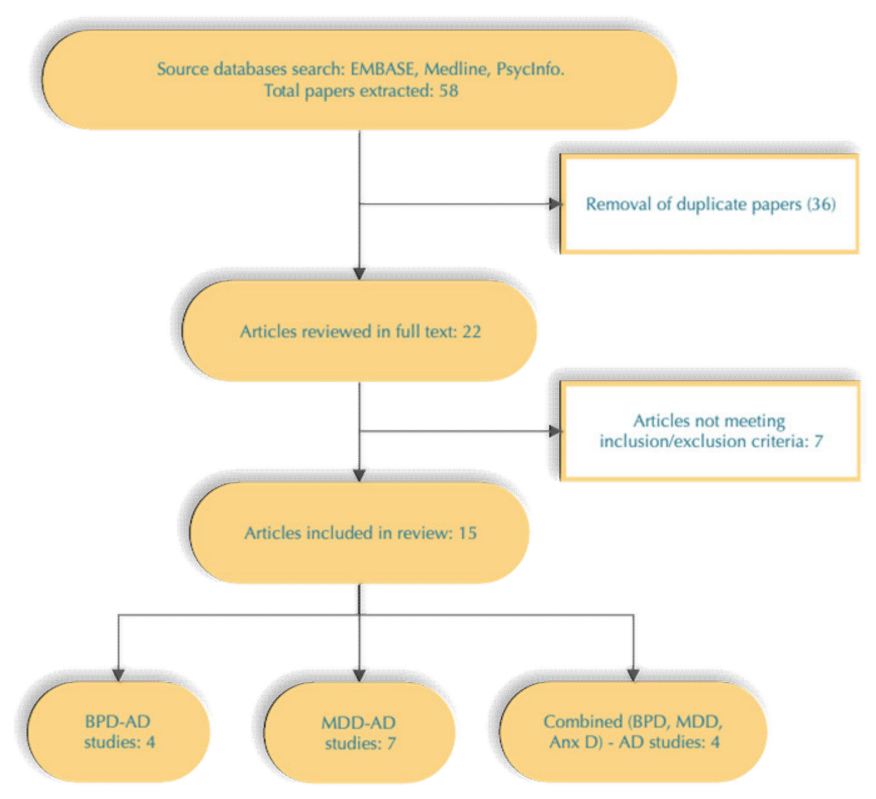

Figure 1. Study selection process.

\section{Results}

This review includes 15 articles focusing on GWAS in samples with AUD and cooccurring mood or anxiety disorders. Both a narrative approach and statistical measures (as presented by authors) were used to summarize results which are presented on Table 1. In the studies looking for a correlation between PRS for MDD and BPD and AUD pheno- 
type, the former was obtained from the following discovery samples: Psychiatric Genetic Consortium (PGC) MDD-PRS1 [43] and MDD-PRS2 [44] and PGC BPD-PRS1 [45]. The majority of studies included subjects of White/Caucasian adults of European-American (EA), African-American (AA) or European ancestry.

Table 1. Overview of GWAS focusing on comorbid mood, anxiety, and alcohol use disorders.

\begin{tabular}{|c|c|c|c|c|}
\hline Study & Sample & $\begin{array}{c}\text { Identified High-Risk } \\
\text { Polymorphisms/PRS Associations }\end{array}$ & Neurobiological Underpinnings & Comments \\
\hline $\begin{array}{l}\text { Lydall et al. } \\
2011[46]\end{array}$ & $\begin{array}{l}506 \text { bipolar I disorder } \\
\text { (BPD-I) cases }(\mathrm{m}=193) \\
\text { from the University College } \\
\text { of London cohort } 1 \text { (UCL1) } \\
\text { and } 510 \text { controls }(\mathrm{m}=217) \text {. } \\
\text { Cases were of English } \\
\text { (Caucasian), Irish, Scots } \\
\text { and Welsh ancestry. Two } \\
\text { phenotypes were defined: } \\
\text { ICD-10/DSM-III-R bipolar } \\
\text { disorder + RDC } \\
\text { alcoholism } \\
\text { (BPALC)-143 cases } \\
\text { (m = 80); Bipolar disorder } \\
\text { without alcoholism } \\
\text { (NABPD)-363 cases } \\
\text { ( } \mathrm{m}=113 \text { ). }\end{array}$ & $\begin{array}{c}\text { Suggestive significance } \\
\left(p<1 \times 10^{-1)}\right) \text { was detected for the } \\
\text { following SNPs, located in or near to } \\
\text { genes previously implicated } \\
\text { in alcoholism: } \\
\text { rs429065 }\left(16 \mathrm{q} 22, p=1.03 \times 10^{-4}\right) \text { in } \\
\text { the region of CDH11 (cadherin } 11 \\
\text { gene); rs } 3130159(\text { chr. } 6 \mathrm{p} 21.3, \\
\left.p=2.83 \times 10^{-3}\right) \text { within COL11A2 } \\
(\text { collagen type } 11 \text { a2 gene); } \\
\text { rs17113138 }\left(5 \mathrm{q} 33.1, p=1.43 \times 10^{-2}\right) \\
\text { within NMUR2 (neuromedin } \mathrm{U} \\
\text { receptor } 2 \text { gene); rs7013323 }(8 \mathrm{p} 21.3 \\
\left.p=7.99 \times 10^{-3}\right) \text { within XPO7 } \\
\text { (exportin } 7 \text { gene); rs2256569 }(5 \mathrm{p} 15.31, \\
\left.p=2.11 \times 10^{-4}\right)- \text { SEMA5A } \\
(\text { semaphorin-associated protein } \\
5 \mathrm{~A} \text { gene). }\end{array}$ & $\begin{array}{l}\text { Cadherin11-belongs to a group of } \\
\text { transmembrane proteins that } \\
\text { mediate Ca }{ }^{++} \text {dependent cell-cell } \\
\text { adhesion and the generation } \\
\text { of synaptic complexity in the } \\
\text { developing brain, implicated in } \\
\text { mnemonic processes, addictions, } \\
\text { and BPD. } \\
\text { COL11A2_encoding one of the two } \\
\text { chains of XI collagen; implicated in } \\
\text { various facial and skeleton bone } \\
\text { dysplasia syndromes as well as } \\
\text { Mendelian inherited } \\
\text { sensorineural deafness; } \\
\text { NMUR2-belongs to the G-protein } \\
\text { coupled receptor } 1 \text { family and is } \\
\text { expressed in guts and CNS } \\
\text { (hypothalamus). It binds to the } \\
\text { neuropeptide U. The receptor plays a } \\
\text { role in food intake and body weight. } \\
\text { XPO7 protein-mediates the nuclear } \\
\text { export of proteins with broad } \\
\text { substrate specificity. Involved in } \\
\text { alcoholism according to the pooled } \\
\text { COGA genome associated data [ } 47 \text {; } \\
\text { SEMA5A-a member of the } \\
\text { semaphorins family of membrane } \\
\text { proteins involved in axonal guidance } \\
\text { during neural development. } \\
\text { Associated with autism } \\
\text { susceptibility. }\end{array}$ & $\begin{array}{l}\text { Most significant SNPs } \\
\text { associations with BPALC } \\
\text { phenotype were within or } \\
\text { near genes involved in cell } \\
\text { adhesion, differentiation } \\
\text { and regulation, } \\
\text { neurotransmitter pathways } \\
\text { and ion function, enzymatic } \\
\text { activity, cellular messengers } \\
\text { (second messengers), } \\
\text { connective tissue. } \\
\text { Association between these } \\
\text { SNPs and the BPALC cases, } \\
\text { but not with NABPD cases } \\
\text { suggests genetic effects on } \\
\text { alcoholism independent of } \\
\text { bipolar affective disorder. } \\
\text { Genes of the } \\
\text { GABA system (e.g., GABA } \\
\text { receptor type 2), which are } \\
\text { among the most replicated in } \\
\text { alcoholism, were not } \\
\text { determined as being } \\
\text { associated with BPALC } \\
\text { phenotype, indicating either } \\
\text { genetic heterogeneity of } \\
\text { alcoholism, or the possibility } \\
\text { that alcoholism in BPD is } \\
\text { mediated by } \\
\text { different pathways. } \\
\text { Limitations: Small sample for } \\
\text { a GWAS. }\end{array}$ \\
\hline $\begin{array}{l}\text { Kerner et al. } \\
2011 \text { [48] }\end{array}$ & $\begin{array}{c}1000 \text { EA }^{2} \text { subjects } \\
(\mathrm{m}=499) \text { with BPD-I } \\
\text { (DSM-IV) and } 1034 \text { controls } \\
(\mathrm{m}=532) \text {. In BPD sample, } \\
250 \text { patients (group 1) had } \\
\text { lifetime alcohol } \\
\text { dependence (AD) with or } \\
\text { without lifetime substance } \\
\text { abuse/dependence } \\
\text { (including nicotine); } 40 \% \text { of } \\
\text { another group of } 270 \\
\text { patients with BPD with } \\
\text { psychotic features (group 2) } \\
\text { had a lifetime alcohol } \\
\text { abuse but not AD. }\end{array}$ & $\begin{array}{l}\text { The SNP rs2727943 (3p26.3, } \\
p=3.36 \times 10^{-8} \text { ) was associated with } \\
\text { OR of } 4.9 \text { for having BD-I with } \\
\text { comorbid alcohol dependence } \\
\text { (group } 1 \text { ) phenotype. This } \\
\text { polymorphism is located between } \\
\text { the genes contactin-4 precursor } \\
\text { (BIG-2) and neural adhesion } \\
\text { molecule contactin } 6(\mathrm{CNTN} 6) \text {. } \\
\text { In group 2, statistical significance on } \\
\text { genome-wide level was detected for } \\
\text { rs1039002 }\left(6 \mathrm{q} 27.5, p=1.7 \times 10^{-8}\right) \\
\text { and rs12563333 }\left(1 \mathrm{q} 41, p=5.9 \times 10^{-8}\right) \text {. } \\
\text { Besides, two SNPs neared } \\
\text { significance: rs } 9493867(6 \mathrm{q} 23.2, \\
p \text {-value from } 1.0 \times 10^{-7} \text { under } \\
\text { recessive model to } 9.0 \times 10^{-8} \text { under } \\
\text { dominant) within the gene encoding } \\
\text { serine/threonine kinase }(\text { Skg1); and } \\
\text { rs13220542 }\left(6 \mathrm{q} 15, p=9.0 \times 10^{-8}\right. \\
\text { under dominant model) located } 3^{\prime} \text { to } \\
\text { the gene coding mitogen-activated } \\
\text { protein kinase, kinase, kinase } 7 \\
\text { (MAP3K7). }\end{array}$ & $\begin{array}{l}\text { The high-risk SNP is located in a } \\
\text { region that is deleted in individuals } \\
\text { with } \\
\text { autistic features. Proteins coded by } \\
\text { BIG-2 and CNTN6 might play a role } \\
\text { in the formation of axon connections } \\
\text { in the developing brain. } \\
\text { rs1039002 is located in transcribed } \\
\text { genomic sequence with } \\
\text { unknown function. The nearest } \\
\text { known gene is phosphodiesterase } 1 \\
\text { (PDE10A) which is involved in the } \\
\text { elimination of intracellular cAMP } \\
\text { and cGMP signaling molecules. } \\
\text { Inhibitors of the PDE10A have } \\
\text { shown therapeutic potential in } \\
\text { Parkinson's and Huntington's } \\
\text { disease, addiction, and OCD and are } \\
\text { being tested in clinical trials. } \\
\text { Rs12563333 is located in a } \\
\text { transcribed sequence immediately } \\
\text { upstream of the gene } \\
\text { MAP/microtubule-affinity } \\
\text { regulating kinase } 1 \text { (MARK1). } \\
\text { MARK1 phosphorylates } \\
\text { microtubules associated proteins } \\
\text { and is involved in synaptic plasticity } \\
\text { and dendritic trafficking. } \\
\text { The two SNPs closing genome- wide } \\
\text { significance are located in genes } \\
\text { involved in response to stress } \\
\text { through K, Na, and Cl channels } \\
\text { (Skg1) and activation of protein } \\
\text { kinases such as MAPK8 and } \\
\text { MAP2K4 (MAP3K7). }\end{array}$ & $\begin{array}{l}\text { The study distinguished three } \\
\text { distinct profiles of } \\
\text { comorbidity in the BP-1 } \\
\text { sample with two of them } \\
\text { significantly associated with } \\
\text { specific SNP/SNPs: a group } \\
\text { with comorbid psychosis and } \\
\text { substance abuse (including } \\
\text { alcohol abuse but no alcohol } \\
\text { dependence); a group with } \\
\text { comorbid alcohol dependence } \\
\text { but also high lifetime } \\
\text { prevalence of comorbid PD; } \\
\text { and a group with a very low } \\
\text { rate of co-morbid conditions. } \\
\text { This suggests that phenotype } \\
\text { heterogeneity in } \\
\text { BPD might indicate genetic } \\
\text { heterogeneity. } \\
\text { The SNPs close to } \\
\text { genome-wide significance are } \\
\text { in genes implicated in stress } \\
\text { response and warrant further } \\
\text { investigation in samples with } \\
\text { BD comorbid with SUD. } \\
\text { Since the associated variants } \\
\text { were rare, future studies } \\
\text { applying re-sequencing of } \\
\text { these chromosomal regions in } \\
\text { BP patients could be more } \\
\text { appropriate for replication. } \\
\text { Limitations: Small sample for } \\
\text { a GWAS. }\end{array}$ \\
\hline
\end{tabular}


Table 1. Cont.

\begin{tabular}{|c|c|c|c|c|}
\hline Study & Sample & $\begin{array}{c}\text { Identified High-Risk } \\
\text { Polymorphisms/PRS Associations }\end{array}$ & Neurobiological Underpinnings & Comments \\
\hline $\begin{array}{l}\text { Edwards et al. } \\
2012[49]\end{array}$ & $\begin{array}{l}467 \text { cases with DSM-IV AD } \\
\text { and major depression } \\
(\mathrm{MDD}) \text { phenotype } \\
(\mathrm{m}=287) \text { and } 407 \\
\text { unaffected controls } \\
(\mathrm{m}=132) \text {. Cases were } \\
\text { drawn from the COGA } \\
\text { study sample [29] and were } \\
\text { from EA and } \mathrm{AA}^{3} \text { descent } \\
\text { (so were controls). }\end{array}$ & $\begin{array}{l}\text { No marker met genome-wide } \\
\text { significance criteria }\left(5 \times 10^{-8}\right) ; 10 \\
\text { SNPs had } p \text { values }<1 \times 10^{-5} \text { and } 7 \\
\text { of them fell into the regions of the } \\
\text { known genes: OXTR (oxytocin } \\
\text { receptor gene), FAF1 (Fas-associated } \\
\text { factor 1), OPA3 (Optic atrophy 3), } \\
\text { EFHA2 (EF-hand domain family, } \\
\text { member 2), FHIT (fragile histidine } \\
\text { triad gene), WDR7 (WD repeat } \\
\text { domain 7), SPATA13 } \\
\text { (spermatogenesis associated 13). } \\
\text { A number of SNPs with } p \text { - } \\
\text { value }<1 \times 10^{-3} \text { were detected in } \\
\text { glutamate receptor genes (GRIN2A, } \\
\text { GRIN2C, and GRID1) which have } \\
\text { been previously associated with } \\
\text { SCH, MDD, and addiction; as well as } \\
\text { within genes previously associated } \\
\text { with depression, AD, or other } \\
\text { addictions (CDH13, CSMD2, and } \\
\text { HTR1B), }\end{array}$ & $\begin{array}{l}\text { FAF1, OPA, EFHA2, and WDR7 } \\
\text { genes encode protein products } \\
\text { engaged in apoptosis (among their } \\
\text { other functions) } \\
\text { FHIT's coded enzyme is involved in } \\
\text { purine metabolism, but also in } \\
\text { protection against DNA damage } \\
\text { SPATA13 encodes a protein involved } \\
\text { in cell migration, adhesion, assembly } \\
\text { and disassembly. } \\
\text { CDH13—a member of the cadherin } \\
\text { family of cell adhesion molecules, } \\
\text { impacts GABA functioning and is a } \\
\text { risk gene for ADHD, SUD, MDD, } \\
\text { and violent behavior; } \\
\text { CSMD2—codes a synaptic } \\
\text { transmembrane protein involved in } \\
\text { the development and maintenance } \\
\text { of dendrites and synapses that has } \\
\text { been linked to schizophrenia and } \\
\text { autistic disorders by GWAS. } \\
\text { HTR1B—codes 5-HT receptor } 1 \mathrm{~B} \\
\text { receptor associated with OCD, } \\
\text { personality disorders, and } \\
\text { schizophrenia. }\end{array}$ & $\begin{array}{l}\text { The degree of overlap of } \\
\text { significant SNPs between a } \\
\text { comorbid phenotype } \\
\text { (AD-MDD) and an AD-only } \\
\text { phenotype is modest } \\
\text { suggesting that comorbid } \\
\text { phenotype is partially } \\
\text { influenced by genetic variants } \\
\text { that do not affect AD alone. } \\
\text { Limitations: small sample } \\
\text { size for GWAS; } \\
>50 \% \text { of cases have not met } \\
\text { DSM-IV criteria for } \\
\text { independent MDD, i.e., } \\
\text { depressive symptoms in them } \\
\text { have occurred under the } \\
\text { influence of alcohol or drugs }\end{array}$ \\
\hline $\begin{array}{l}\text { Sharp et al. } \\
(2014) \text { [50] }\end{array}$ & $\begin{array}{l}\text { The sample consisted of } \\
2096 \text { patients and } 1056 \\
\text { controls. Patients were } \\
\text { distributed as follows: 506 } \\
\text { BPD-I cases from UCL1; } \\
593 \text { cases (m = 219) from } \\
\text { the University College of } \\
\text { London cohort } 2 \text { (UCL2), of } \\
\text { which } 409 \text { were with BPD-I } \\
\text { and } 184 \text { with BPD-II; } \\
997 \text { AD syndrome cases } \\
\text { from the University College } \\
\text { of London ADS sample } \\
\text { (UCL ADS) part of the } \\
\text { UK-COGA project; } 35 \text { cases } \\
\text { of ADHD }{ }^{4} \text { Cases were of } \\
\text { English (Caucasian), Irish, } \\
\text { Scots, and Welsh ancestry. } \\
\text { Control subjects were } \\
\text { comprised of } 672 \text { screened } \\
\text { individuals without mental } \\
\text { disorder or family history } \\
\text { for schizophrenia, AD, } \\
\text { BPALC, and } 384 \\
\text { unscreened ones. }\end{array}$ & $\begin{array}{c}\text { Two SNPs in tachykinin receptor } 1 \\
\text { gene (TACR1, } 2 \text { p12) were } \\
\text { significantly associated with BPD } \\
\text { cases in comparison with screened } \\
\text { controls-rs3771829 }(p=0.002, \text { OR } \\
\text { 1.57) and rs3771833 ( } p=0.004, \text { OR } \\
\text { 1.43). However, neither of the two } \\
\text { were associated with BPD in the } \\
\text { UCL2 sample alone. } \\
\text { In comparison with controls, } \\
\text { rs3771829 was significantly } \\
\text { associated with BPD (UCL1 and } \\
\text { UCL2 combined, } p=9.0 \times 10^{-8} \\
\text { under dominant model), ADS } \\
\left(p=2.0 \times 10^{-3}\right) \text { and BPALC } \\
\left(p=6.0 \times 10^{-4}\right) \text {. } \\
\text { DNA sequencing in selected cases of } \\
\text { BPD and ADHD with inherited } \\
\text { TACR1-susceptibility haplotypes } \\
\text { determined } 19 \text { SNPs in different } \\
\text { regions of TACR1 that increase } \\
\text { vulnerability to BPD, ADS, ADHD, } \\
\text { and BPALC. } \\
\text { The association with TACR1 } \\
\text { and BPAD, ADS, and ADHD } \\
\text { suggests a shared molecular } \\
\text { pathophysiology } \\
\text { between these disorders. }\end{array}$ & $\begin{array}{l}\text { Neurokinin } 1 \text { receptors (NK1R) } \\
\text { encoded by TACR1 are abundantly } \\
\text { expressed throughout brain regions } \\
\text { driving reward and reinforcement. } \\
\text { The binding density of NK1R is } \\
\text { highest in the locus coeruleus } \\
\text { involved in mood regulation and } \\
\text { response to stress. Inactivation of } \\
\text { NK1Rs critically modulates alcohol } \\
\text { reward and escalation, supporting a } \\
\text { direct role of NK1R in the regulation } \\
\text { of alcohol intake and the } \\
\text { development of alcohol dependence. } \\
\text { NK1Rs are an attractive molecular } \\
\text { target for the treatment of alcohol } \\
\text { use disorders but also depression } \\
\text { and anxiety. Trials of the efficacy of } \\
\text { NK1R antagonists in ADS are } \\
\text { currently underway. }\end{array}$ & $\begin{array}{l}\text { The lack of association of the } \\
\text { two top marker SNPs with } \\
\text { BPD in UCL2 sample may } \\
\text { reflect both the heterogeneity } \\
\text { of BPD susceptibility genes } \\
\text { even in single ancestrally } \\
\text { originating cases, as well as } \\
\text { the presence of low frequency } \\
\text { disease alleles. } \\
\text { Differences of association of } \\
\text { rs3771829 and rs3771833 was } \\
\text { stronger for BPALC only } \\
\text { compared to screened } \\
\text { controls than for BPD-total } \\
\text { compared to screened } \\
\text { controls. Therefore, it is likely } \\
\text { that the comorbid ADS in } \\
\text { BPD cohort is driving the } \\
\text { association, i.e., NK1Rs are } \\
\text { more strongly implicated in } \\
\text { the neurobiology of alcohol } \\
\text { use disorders than in BPD. } \\
\text { Limitations: Small sample for } \\
\text { a GWAS. }\end{array}$ \\
\hline
\end{tabular}


Table 1. Cont.

\begin{tabular}{|c|c|c|c|c|}
\hline Study & Sample & $\begin{array}{c}\text { Identified High-Risk } \\
\text { Polymorphisms/PRS Associations }\end{array}$ & Neurobiological Underpinnings & Comments \\
\hline $\begin{array}{l}\text { Levey et al. } \\
2014[51]\end{array}$ & $\begin{array}{l}7948 \text { subjects ( } 4519 \text { patients } \\
\text { and } 3429 \text { controls). Patients } \\
\text { were distributed as follows: } \\
1151 \text { men from } \\
\text { German-Caucasian descent } \\
\text { with AD [52,53]; } \\
2768 \text { patients }(\mathrm{m}=1687) \\
\text { from EA }(n=1273) \text { and AA } \\
(n=1495) \text { origin with AD; } \\
600 \text { patients }(\mathrm{m}=366) \text { from } \\
\text { EA ( } 324) \text { and AA }(n=276) \\
\text { origin with alcohol abuse. } \\
\text { Controls were distributed } \\
\text { as follows: } \\
2168 \text { subjects form } \\
\text { German-Caucasian descent } \\
\text { (m = 939); } \\
1261 \text { subjects (m }=475) \\
\text { from EA ( } 388) \text { and AA }(873) \\
\text { descent. }\end{array}$ & $\begin{array}{c}\text { Authors used a translational } \\
\text { Convergent Functional Genomics } \\
\text { (CFG) approach to discover genes } \\
\text { involved in alcoholism by } \\
\text { integration of GWAS data with other } \\
\text { genetic and gene-expression data } \\
\text { from human and animal } \\
\text { model studies. } \\
\text { Top } 11 \text { candidate genes for } \\
\text { alcoholism detected by this study } \\
\text { ( } p=0.041 \text { ) were explored for the } \\
\text { degree of overlap with risk genes for } \\
\text { BPD and anxiety disorders in } \\
\text { previous studies of the same group } \\
\text { with a similar design [54,55]. } \\
\text { Besides, the association of Genetic } \\
\text { Risk Predictive Panel for BPD (i.e., } \\
\text { list of top risk SNPs in } 56 \text { genes } \\
\text { involved in BPD) identified by the } \\
\text { same authors in a previous study } \\
\text { [54] was tested in AD, AA, and } \\
\text { Control samples of the current study. } \\
\text { Results: SNPs in SNCA (rs17015888) } \\
\text { and DRD2 were shared among } \\
\text { anxiety disorder and alcoholism } \\
\text { samples while GNAI1, GRM3 } \\
\text { (rs17160519 to rs } 4236502), \text { and MBP } \\
\text { genes showed involvement in BPD } \\
\text { and alcoholism. } \\
\text { Genetic risk prediction score for BP } \\
\text { showed increased genetic load for } \\
\text { bipolar disorder in both alcohol } \\
\text { dependence }\left(p=9.94 \times 10^{-8} \text { ) and }\right. \\
\left.\text { alcohol abuse ( } p=1.18 \times 10^{-4}\right) \text {. }\end{array}$ & $\begin{array}{l}\text { SNCA (synuclein alpha), a } \\
\text { pre-synaptic chaperone, has been } \\
\text { reported previously as being } \\
\text { involved in modulating brain } \\
\text { plasticity and neurogenesis, as well } \\
\text { as neurotransmission, primarily as a } \\
\text { brake. On the pathological side, low } \\
\text { levels of SNCA might offer less } \\
\text { protection against oxidative stress, } \\
\text { whereas high levels of SNCA may } \\
\text { have a role in neurodegenerative } \\
\text { diseases, like Parkinson's disease. } \\
\text { SNCA has been described as a } \\
\text { susceptibility gene for alcohol } \\
\text { cravings and response to alcohol } \\
\text { cues. } \\
\text { DRD2 (dopamine } 2 \text { receptor gene) } \\
\text { has shown reduced expression in the } \\
\text { brains of alcoholics and one possible } \\
\text { explanation for this, bridging the } \\
\text { common role of this receptor in AUD } \\
\text { and BPD, is that both conditions } \\
\text { include hyperdopaminergic state } \\
\text { which drives individuals to } \\
\text { hedonistic activities and leads to } \\
\text { homeostatic downregulation of their } \\
\text { DRD2 receptors. An alternative } \\
\text { hypothesis sees lower levels of } \\
\text { dopamine receptors as a reflection of } \\
\text { reduced dopaminergic signaling and } \\
\text { anhedonia, leading individuals to } \\
\text { overcompensate by alcohol and } \\
\text { drug abuse. } \\
\text { GRM3 belongs to the metabotropic } \\
\text { glutamate receptors family (G } \\
\text { protein-coupled receptors), i.e., it is } \\
\text { heavily involved in } \\
\text { neurotransmitter signaling. GRM3 } \\
\text { has been exclusively associated with } \\
\text { BPD so far. } \\
\text { MBP (Myelin Basic Protein gene) } \\
\text { Subunit Alpha-1 gene) encodes a } \\
\text { protein that is part of a complex that } \\
\text { responds to beta-adrenergic signals } \\
\text { by inhibiting adenylate cyclase. } \\
\text { myelin sheath of oligodendrocytes } \\
\text { and Schwann cells } \\
\text { GNAI1 (Guanine }\end{array}$ & $\begin{array}{l}\text { The GWAS study on which } \\
\text { discovery was based } \\
\text { contained males as probands } \\
\text { and males and females as } \\
\text { controls. } \\
\text { Therefore, it is possible that } \\
\text { some of the nominally } \\
\text { significant SNPs detected } \\
\text { have to do with gender } \\
\text { differences rather than with } \\
\text { alcoholism per se, or at least, } \\
\text { are limited to male } \\
\text { alcoholism. Stratification } \\
\text { across gender and } \\
\text { ethnicities may have also } \\
\text { been a confounding factor in } \\
\text { US samples. Possible } \\
\text { ethnicity differences in alleles, } \\
\text { genes, and the consequent } \\
\text { neurobiology need to be } \\
\text { explored in further larger } \\
\text { sample studies, taking into } \\
\text { account environmental } \\
\text { and cultural factors. } \\
\text { Limitations: Small sample for } \\
\text { a GWAS. }\end{array}$ \\
\hline
\end{tabular}


Table 1. Cont.

\begin{tabular}{|c|c|c|c|c|}
\hline Study & Sample & $\begin{array}{c}\text { Identified High-Risk } \\
\text { Polymorphisms/PRS Associations }\end{array}$ & Neurobiological Underpinnings & Comments \\
\hline $\begin{array}{l}\text { Carey et al. } \\
2016[56]\end{array}$ & $\begin{array}{l}1160 \text { cases and } 1413 \\
\text { controls ( } \mathrm{f}=56 \% \text { ) included } \\
\text { in SAGE [57] and sampled } \\
\text { from three previous } \\
\text { studies-COGA [29], } \\
\text { COGEND [58], and FSCD } \\
\text { [59]. Cases were of } \\
\text { non-Hispanic EA ancestry. } \\
\text { In addition to meeting } \\
\text { DSM-IV AD criteria, they } \\
\text { often met criteria for } \\
\text { cocaine, cannabis, and } \\
\text { opioid dependence. } \\
\text { A measure of general } \\
\text { substance involvement } \\
\text { (GENSUB) was generated } \\
\text { by factor analysis of the } \\
\text { individual substance } \\
\text { involvement measures } \\
\text { (types of substances and } \\
\text { frequency of use). } \\
\text { Associations between } \\
\text { PGC-PRS-MDD1 and } \\
\text { PGC-PRS-BPD1 and } \\
\text { involvement in AD were } \\
\text { tested. } \\
\text { PRS-MDD1 includes }>200 \\
\text { SNPs related to }>180 \text { genes } \\
\text { associated with synaptic } \\
\text { function and } \\
\text { neurotransmission and } \\
\text { especially expressed in } \\
\text { prefrontal brain areas. } \\
\text { BP-PRS1 includes SNPs } \\
\text { within or near genes } \\
\text { implicated in cell adhesion } \\
\text { and migration as well as } \\
\text { coding of calcium and } \\
\text { other ion channels, } \\
\text { neurotransmitter receptors, } \\
\text { and synaptic components. }\end{array}$ & $\begin{array}{l}\text { MDD-PRS/Alcohol Dependence: } \\
\text { suggestive significance }(p<0.0001 \text {, } \\
\text { OR } 1.23,95 \% \text { CI) was found for } \\
\text { associated MDD-PRS and severe } \\
\text { alcohol dependence (6-7 } \\
\text { dependence symptoms), supporting } \\
\text { shared genetic liability to MDD and } \\
\text { AD. Current MDD-PRS explain } \\
\text { roughly } 1 \% \text { of the variance in } \\
\text { general substance involvement } \\
\text { (GENSUB). } \\
\text { BPD-PRS/Alcohol Dependence: } \\
\text { there was evidence for a } \\
\text { dose-dependent relationship } \\
\text { between BPD-PRS and an increasing } \\
\text { number of alcohol dependence } \\
\text { symptoms among regular drinkers } \\
\text { with at least one symptom of } \\
\text { dependence. } \\
\text { Association of BPD-PRS with } \\
\text { GENSUB (i.e., involvement in } \\
\text { multiple substances) was much } \\
\text { stronger than that for alcohol alone. }\end{array}$ & $\begin{array}{l}\text { MDD/Alcohol Dependence: } \\
\text { together with data from previous } \\
\text { GWAS showing significant } \\
\text { overlapping regions/variants } \\
\text { contributing specifically to MDD } \\
\text { alone, MDD with a comorbid SUD, } \\
\text { or a combined MDD and SUD } \\
\text { phenotype only, these results suggest } \\
\text { that relationships between MDD and } \\
\text { alcohol and MDD and other } \\
\text { substances (cocaine) are } \\
\text { substance-specific. } \\
\text { The overall association with general } \\
\text { substance involvement liability may } \\
\text { be reflective of similar cognitive } \\
\text { mechanisms (e.g., impulsivity, } \\
\text { emotion dysregulation, sensation- } \\
\text { seeking) that are thought to broadly } \\
\text { underlie both BPD and substance } \\
\text { use disorders. Such a mechanism fits } \\
\text { well with the hypothesis for a genetic } \\
\text { basis of the BPD-SUD comorbidity } \\
\text { supported by many studies. }\end{array}$ & $\begin{array}{l}\text { Limitations: } 1 \text {. Small sample } \\
\text { for a GWAS. Nominal } \\
\text { associations may strengthen } \\
\text { with larger discovery samples } \\
\text { (e.g., samples from which } \\
\text { PRS are extracted), as well as } \\
\text { larger target samples. } \\
\text { 2. While the study confirms } \\
\text { that shared genetic } \\
\text { architecture contributes to } \\
\text { mood disorders and } \\
\text { substance use disorders, it } \\
\text { does not reveal specific } \\
\text { biological (e.g., } \\
\text { reward-related neural } \\
\text { responsiveness, epigenetically } \\
\text { driven gene expression } \\
\text { changes), psychological (e.g., } \\
\text { anhedonia, impulsivity), } \\
\text { and/or experiential (e.g., } \\
\text { early life stress, peer group } \\
\text { pressure) mechanisms } \\
\text { through which risk is } \\
\text { manifested. }\end{array}$ \\
\hline $\begin{array}{l}\text { Andersen et al. } \\
\text { 2017 [60] }\end{array}$ & $\begin{array}{l}3871 \text { DSM-IV-AD cases } \\
(\mathrm{m}=2551) \text { and } 3347 \\
\text { controls }(\mathrm{m}=2082) \text { from } \\
\text { four different study } \\
\text { samples-COGA [29], } \\
\text { SAGE [57], Yale-Penn [61], } \\
\text { and NHRVS [62]. Subjects } \\
\text { were of } \\
\text { European-American } \\
\text { ancestry. The prevalence of } \\
\text { MDD among AD patients } \\
\text { in the different samples } \\
\text { was between } 19 \text { and } 35 \% \\
\text { and for controls-between } \\
\text { 6.3 and } 12.5 \% \text {. } \\
\text { Associations between } \\
\text { PGC-MDD-PRS1 and AD } \\
\text { were performed with the } \\
\text { analysis corrected for age, } \\
\text { sex, and population } \\
\text { stratification. }\end{array}$ & $\begin{array}{c}\text { A significant association was } \\
\text { observed between MDD-PRS and } \\
\text { AD case-control status for all four } \\
\text { AD samples }\left(p=3.3 \times 10^{-9} ; p \text { value }\right. \\
\text { threshold }=0.4) \text {. } \\
\text { The proportion of variance in AD } \\
\text { explained by the MDD-PRS was } \\
\text { small ( } R^{2} \text { value of } 0.0018 \text { (min.) and } \\
0.026 \text { (max). Association remained } \\
\text { even when recalculated MDD-PRS } \\
\text { from GWAS-MDD samples without } \\
\text { comorbid MDD-AD cases was used } \\
\text { in analyses performed only for those } \\
\text { patients from the four samples with } \\
\text { pure AD (i.e., without MDD), } \\
\text { providing further support for the } \\
\text { genetic overlap between MDD and } \\
\text { AD. } \\
\text { No difference in the strength or } \\
\text { significance or associations between } \\
\text { MDD-PRS and AD status by sex was } \\
\text { observed. }\end{array}$ & $\begin{array}{l}\text { Although studies like the current } \\
\text { one cannot, due to their design, } \\
\text { determine the mechanisms by which } \\
\text { shared genetic liability for MDD and } \\
\text { AD operate, there are some } \\
\text { suggestive possibilities that should } \\
\text { be tested by future studies. For } \\
\text { example, anxiety may be a } \\
\text { significant factor linking AD and } \\
\text { MDD via the internalizing pathway. } \\
\text { Furthermore, broader personality } \\
\text { traits such as neuroticism, } \\
\text { disinhibition, and sensation seeking } \\
\text { are potentially associated with a } \\
\text { range of internalizing and } \\
\text { externalizing psychiatric disorders, } \\
\text { including comorbidity of MDD and } \\
\text { AD. }\end{array}$ & $\begin{array}{l}\text { Limitations: } 1 \text {. MDD-GWAS } \\
\text { with larger sample sizes will } \\
\text { likely improve the predictive } \\
\text { ability of MDD PRS and } \\
\text { probably lead to refinement } \\
\text { of observed associations. } \\
2 \text {. The study included only } \\
\text { AD case (and not other SUDs) } \\
\text { and for this reason further } \\
\text { studies are needed to check } \\
\text { whether the MDD-PRS } \\
\text { association is specific to AD } \\
\text { or it generalizes to substance } \\
\text { dependence broadly as } \\
\text { suggested by existing } \\
\text { research data. }\end{array}$ \\
\hline
\end{tabular}


Table 1. Cont.

\begin{tabular}{|c|c|c|c|c|}
\hline Study & Sample & $\begin{array}{c}\text { Identified High-Risk } \\
\text { Polymorphisms/PRS Associations }\end{array}$ & Neurobiological Underpinnings & Comments \\
\hline $\begin{array}{l}\text { Zhou et al. } \\
\text { 2017 [63] }\end{array}$ & $\begin{array}{l}7822 \text { subjects }(\mathrm{m}=4480) \\
\text { from EA (3169) and AA } \\
(4653) \text { descent from the } \\
\text { Yale-Penn Study [61] with } \\
\text { lifetime DSM-IV AD and } \\
\text { MDD diagnosis. The } \\
\text { participants were divided } \\
\text { into Yale-Penn } 1 \text { and } \\
\text { Yale-Penn } 2 \text { subsamples } \\
\text { based on the period of } \\
\text { recruitment (between } 1999 \\
\text { and 2015) and on the } \\
\text { genotyping platform used. }\end{array}$ & $\begin{array}{c}\text { The SNP rs139438618 at the } \\
\text { SEMA3A (semaphorin } 3 \mathrm{~A}) \text { gene } \\
\text { locus was significantly associated } \\
\text { with AD and MD comorbidity in AA } \\
\text { participants in the Yale-Penn } 1 \\
\left(\beta=0.89 ; p=2.76 \times 10^{-8}\right) \text { and } \\
\text { Yale-Penn } 2(\beta=0.83 \text {; } \\
\left.\qquad p=2.06 \times 10^{-4}\right) \\
\text { There was no significant association } \\
\text { identified in EA participants. } \\
\text { Analyses of PRS showed that } \\
\text { individuals with a higher } \\
\text { risk of neuroticism or depressive } \\
\text { symptoms and a lower level of } \\
\text { subjective well-being and } \\
\text { educational attainment had a higher } \\
\text { level of AD and MD comorbidity, } \\
\text { while larger intracranial and smaller } \\
\text { putamen volumes were associated } \\
\text { with higher risks of AD and MD } \\
\text { comorbidity. }\end{array}$ & $\begin{array}{l}\text { Rs139438618 is located in the intron } \\
\text { part of the SEMA3A gene (7q21.11), } \\
\text { which codes the homonymous } \\
\text { protein part of the semaphorin } \\
\text { family. The latter consists of } \\
\text { transmembrane and secretion } \\
\text { proteins involved in the axonal } \\
\text { growth and connectivity acting like } \\
\text { chemorepulsors (inhibitors of axonal } \\
\text { sprouts) or chemoattractants } \\
\text { (stimulators of apical dendrites). The } \\
\text { expression of these genes is most } \\
\text { intensive in early fetal development } \\
\text { in the olfactory brain and cerebral } \\
\text { and entorhinal cortex. Previous } \\
\text { studies have confirmed their role in } \\
\text { schizophrenia, Alzheimer's disease, } \\
\text { epilepsy, and amyotrophic lateral } \\
\text { sclerosis as well as intestinal } \\
\text { malformations (Hirschprung } \\
\text { disease). } \\
\text { AD-MDD phenotype was associated } \\
\text { with neuroticism PRS including } 11 \\
\text { significant SNPs on chromosomes } 3, \\
8,9,11,15,17,18 \text {. One of them, on } \\
\text { chromosome } 8 \text {, is in the zone of } \\
\text { MSRA and MTMR9 genes which are } \\
\text { both expressed in CNS and code } \\
\text { products engaged in repair of } \\
\text { oxidatively damaged proteins } \\
\text { (MSRA) and cell proliferation control } \\
\text { (MTRM9). Both of them are } \\
\text { significantly associated with } \\
\text { depression/neuroticism and low } \\
\text { subjective well-being according to a } \\
\text { large GWAS (n = 170,000) [64]. In } \\
\text { addition to that, MTRM9 has also } \\
\text { been linked to generalized epilepsy } \\
\text { with febrile seizures. }\end{array}$ & \multirow[t]{2}{*}{$\begin{array}{l}\text { The rs139438618 SNP has not } \\
\text { so far been identified as risk } \\
\text { associated in GWAS studies } \\
\text { with pure MDD and pure AD } \\
\text { phenotypes, which suggests a } \\
\text { pleiotropic effect on the level } \\
\text { of a single gene. } \\
\text { The presence of this SNP AA } \\
\text { only is likely to represent a } \\
\text { populational genetic effect. }\end{array}$} \\
\hline $\begin{array}{l}\text { Reginsson et al. } \\
\text { 2018 [65] }\end{array}$ & $\begin{array}{l}8701 \text { cases }(\mathrm{f}=32.7 \%) \text { of } \\
\text { alcohol use disorder } \\
\text { (DSM-IIIR and DSM-IV) } \\
\text { were part of a larger sample } \\
\text { (n = 144,609) of Icelandic } \\
\text { subjects, including } 10,036 \\
\text { individuals admitted for } \\
\text { in-patient addiction } \\
\text { treatment, 35,754 smokers, } \\
\text { and a group of patients } \\
\text { with schizophrenia } \\
\text { (n = 600) and BPD ( }=772 \text { ). } \\
\text { PGC-BPD1 PRS was tested } \\
\text { for association with alcohol } \\
\text { dependence. }\end{array}$ & $\begin{array}{l}\text { Higher BPD1-PRS was associated } \\
\text { with increased risk of alcohol use } \\
\text { disorder }\left(p=1.7 \times 10^{-9}\right) \text { and with } \\
\text { earlier onset of substance use } \\
\text { problems (including alcohol) } \\
\left(\mathrm{OR}=1.16, p=1.9 \mathrm{~h} 10^{-3}\right) \text {. } \\
\text { Only alcohol use disorder }(\text { and not } \\
\text { smoking and other substance use } \\
\text { disorders) was nominally } \\
\text { associated }(\mathrm{OR}=1.09, \mathrm{R} 2=0.59 \% \text {, } \\
\left.p=2.7 \times 10^{-3}\right) \text { with BPD-PRS when } \\
\text { including PGC-SCZ-PRS [66] } \\
\text { as a covariate. This implies that } \\
\text { alcoholism may share common } \\
\text { genetic causal factors with BPD to a } \\
\text { larger extent than smoking and other } \\
\text { substance use disorders do. }\end{array}$ & $\begin{array}{l}\text { The results support the notion of } \\
\text { common genetic roots of the } \\
\text { comorbidity between addiction } \\
\text { (including alcohol addiction) and } \\
\text { severe mental disorders such as BPD } \\
\text { and schizophrenia, as opposed to } \\
\text { solely being a direct consequence. }\end{array}$ & \\
\hline
\end{tabular}


Table 1. Cont.

\begin{tabular}{|c|c|c|c|c|}
\hline Study & Sample & $\begin{array}{c}\text { Identified High-Risk } \\
\text { Polymorphisms/PRS Associations }\end{array}$ & Neurobiological Underpinnings & Comments \\
\hline $\begin{array}{l}\text { Muench et al. } \\
2018[67]\end{array}$ & 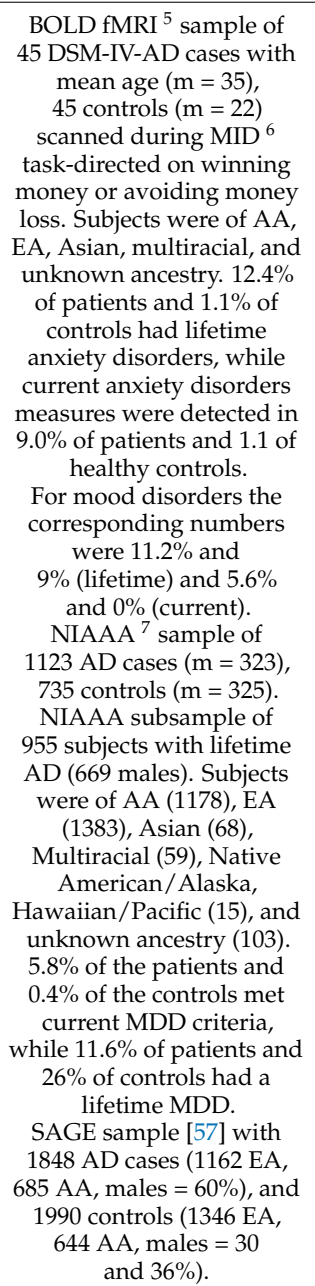 & $\begin{array}{l}\text { Suggestive significance }(p=0.09) \\
\text { was found for the previously } \\
\text { associated with MDD risk variant } \\
\text { rs10514299 within TMEM161B- } \\
\text { MEF2C gene cluster containing } \\
\text { Transmembrane Protein 161B gene } \\
\text { and myocyte enhancer factor } 2 C \\
\text { gene. Carrying the minor T allele } \\
\text { (TT/CT and not CC) was associated } \\
\text { with a lifetime diagnosis of AD } \\
\text { (odds ratio }=0.82, p=0.09 \text { ) in the } \\
\text { NIAAA sample. } \\
\text { The T allele of rs10514299 was } \\
\text { significantly associated with greater } \\
\text { depression symptom severity in } \\
\text { individuals with a lifetime AD } \\
\text { diagnosis ( } \beta=1.25, p=0.02 \text { ) in the } \\
\text { NIAAA sample with this finding } \\
\text { driven by individuals of } \\
\text { AA ancestry. }\end{array}$ & $\begin{array}{l}\text { TMEM161B's function is unclear, } \\
\text { with gene ontology annotation } \\
\text { related to it include nucleic acid } \\
\text { binding. MEF2C encodes a } \\
\text { transcription factor that has been so } \\
\text { far associated with epilepsy and } \\
\text { intellectual disability. } \\
\text { Carrying the T allele in rs10514299 } \\
\text { was associated with a significant } \\
\text { increase in putamen activation } \\
\text { during high and low loss } \\
\text { anticipation in patients with AD, but } \\
\text { with a significant decrease in the } \\
\text { controls, indicating that the allele } \\
\text { differentially affects this neural } \\
\text { phenotype in AD. } \\
\text { Hence, MDD risk variant rs10514299 } \\
\text { in TMEM161B- MEF2C gene cluster } \\
\text { was shown for the first time to } \\
\text { predict neuronal correlates of reward } \\
\text { processing in an AD phenotype } \\
\text { implying possible eligibility of this } \\
\text { polymorphism as a biomarker for } \\
\text { disrupted reward processing in AD } \\
\text { individuals. } \\
\text { The fact that a MDD risk variant was } \\
\text { also shown to be relevant to AD } \\
\text { phenotype supports } \\
\text { a potential role of the respective } \\
\text { genetic locus in an endophenotype } \\
\text { related to deficit of reward } \\
\text { processing (i.e., anhedonia). }\end{array}$ & $\begin{array}{c}\text { Limitations: } 1 \text {. No correction } \\
\text { for multiple comparisons was } \\
\text { done, therefore future } \\
\text { confirmatory analyses are } \\
\text { needed to validate the } \\
\text { functional relevance of } \\
\text { rs10514299. } \\
\text { 2. Insufficient sample size to } \\
\text { detect firmly the likely small } \\
\text { effect size of this SNP. } \\
\text { In co-occurrence of anxiety } \\
\text { disorders for example (GAD, } \\
\text { panic disorder and phobias), } \\
\text { studies reporting suggestively } \\
\text { shared genetic susceptibility } \\
\text { loci have employed much } \\
\text { larger samples [68]. }\end{array}$ \\
\hline $\begin{array}{l}\text { Foo et al. } \\
2018 \text { [69] }\end{array}$ & $\begin{array}{c}\text { Target sample AD: } 1333 \\
\text { German-Caucasian male } \\
\text { DSM-IV-AD cases and } 1307 \\
\text { German-Caucasian controls } \\
\text { from both sexes. A subset } \\
\text { of the AD cases ( } n=332) \\
\text { was recruited explicitly } \\
\text { excluding comorbid MDD. } \\
\text { Target sample MDD: } \\
597 \text { cases and } 1292 \text { controls } \\
\text { from German-Caucasian } \\
\text { ancestry ( } 52,53) . \\
\text { Discovery samples: } \\
\text { PGC-PRS-MDD1 } \\
\text { (8148 cases, } 7955 \text { controls); } \\
\text { PGC-PRS-MDD2 (59,265 } \\
\text { cases, 112,092 controls). }\end{array}$ & 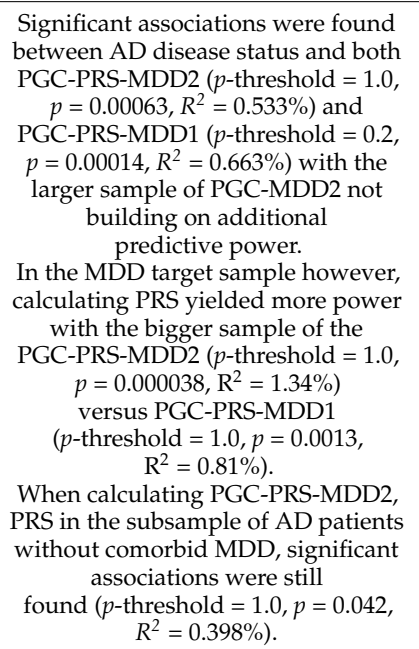 & $\begin{array}{l}\text { The presence of an association } \\
\text { between AD disease status and } \\
\text { PRS-MDD in a subsample of AD } \\
\text { cases without comorbid MDD } \\
\text { supports the hypothesis for a } \\
\text { substantial genetic overlap between } \\
\text { AD and MDD. } \\
\text { Although PRS association studies } \\
\text { like the present one do not, for the } \\
\text { reason of design, possess the power } \\
\text { to predict suggestive neurobiological } \\
\text { pathways explaining comorbid } \\
\text { phenotypes, the authors } \\
\text { hypothesized that the level and risk } \\
\text { of AD and MDD comorbidity may } \\
\text { be linked to neuropsychiatric traits } \\
\text { and brain volumes. }\end{array}$ & $\begin{array}{l}\text { Limitations: determining } \\
\text { shared genetic etiology in } \\
\text { comorbid disorders is } \\
\text { inevitably facing the problem } \\
\text { of "enrichment" of the } \\
\text { comorbid disorders in } \\
\text { discovery and target samples. } \\
\text { In the current study, there } \\
\text { was no information regarding } \\
\text { the AD comorbidity of the } \\
\text { PGC-PRS-MDD2 sample. For } \\
\text { that reason, future studies } \\
\text { should employ rigorous } \\
\text { phenotyping and improved } \\
\text { characterization of samples } \\
\text { with particular detailed } \\
\text { assessment of comorbidity, } \\
\text { symptomatology, } \\
\text { and severity. }\end{array}$ \\
\hline
\end{tabular}


Table 1. Cont.

\begin{tabular}{|c|c|c|c|c|}
\hline Study & Sample & $\begin{array}{c}\text { Identified High-Risk } \\
\text { Polymorphisms/PRS Associations }\end{array}$ & Neurobiological Underpinnings & Comments \\
\hline $\begin{array}{l}\text { Walters et al. } \\
2018[70]\end{array}$ & $\begin{array}{l}14,904 \text { individuals with } \\
\text { DSM-IV-AD and } 37,944 \\
\text { controls from } 28 \\
\text { case-control and } \\
\text { family-based studies } \\
\text { conducted in USA, Europe } \\
\text { and Australia. Data were } \\
\text { stratified by genetic } \\
\text { ancestry (European, } \\
n=46,568 ; \text { African, } \\
n=6280 \text { ). }\end{array}$ & $\begin{array}{c}\text { Independent, genome-wide } \\
\text { significant effects of different } \\
\text { Aldehyde Dehydrogenase } 1 B(\mathrm{ADH} 1 \mathrm{~B}) \\
\text { gene variants were identified in } \\
\text { European }(\mathrm{rs} 1229984 ; \\
\left.p=9.8 \times 10^{-13}\right) \text { and African } \\
\text { ancestries }\left(\mathrm{rs} 2066702 ; p=2.2 \times 10^{-9}\right) \\
\text { Significant genetic correlations were } \\
\text { observed between AD and } 17 \\
\text { phenotypes in unrelated European } \\
\text { samples }(10,206 \text { AD cases and } 28,480 \\
\text { controls), including neuroticism } \\
\left(p=2 \times 10^{-6}\right), \text { depressive symptoms } \\
\left(p=3 \times 10^{-7}\right) \text {, and MDD } \\
\left(p=3 \times 10^{-11}\right) \text {. }\end{array}$ & $\begin{array}{l}\text { Given the stringent criteria for } \\
\text { patient selection in the study sample } \\
\text { (i.e., all individuals were with } \\
\text { confirmed AD diagnosis and not less } \\
\text { severe forms of alcohol misuse), } \\
\text { MDD may primarily share genetic } \\
\text { liability with alcohol use at } \\
\text { pathological levels and on a } \\
\text { molecular level, pleiotropic effects } \\
\text { may be implicated. }\end{array}$ & $\begin{array}{l}\text { There is a continuing need to } \\
\text { characterize the genetic } \\
\text { architecture of AD in non-EU } \\
\text { populations and test the } \\
\text { genetic correlation between } \\
\text { this phenotype and } \\
\text { mood/anxiety phenotypes in } \\
\text { individuals from } \\
\text { non-European ancestry. } \\
\text { Larger future samples will } \\
\text { allow us to uncover } \\
\text { additional pleiotropy } \\
\text { between pathological and } \\
\text { non-pathological alcohol use, } \\
\text { as well as between AD and } \\
\text { other } \\
\text { neuropsychiatric disorders. }\end{array}$ \\
\hline $\begin{array}{l}\text { Polimanti et al. } \\
\text { 2019 [71] }\end{array}$ & $\begin{array}{c}\text { PGC-MDD2 sample } \\
\text { (135,458 cases and 344,901 } \\
\text { controls); PGC-AD sample } \\
\text { 10,206 cases and 28,480 } \\
\text { controls; } \\
\text { UK Biobank sample [72] } \\
\text { 428,308 individuals from } \\
\text { white British ancestry. } \\
\text { Four phenotypes were } \\
\text { defined: MDD, AD, } \\
\text { Alcohol } \\
\text { Consumption-Frequency } \\
\text { (AC-f), and Alcohol } \\
\text { Consumption-Quantity } \\
\text { (AC-q). }\end{array}$ & $\begin{array}{l}\text { Linkage disequilibrium score } \\
\text { regression and Mendelian } \\
\text { randomization (MR) showed a } \\
\text { positive genetic correlation between } \\
\text { MD and AD. AC-q demonstrated a } \\
\text { positive correlation with both AD } \\
\text { and MD, while AC-f had a negative } \\
\text { correlation with MDD and } \\
\text { non-significant with AD. } \\
\text { MR analyses confirmed the presence } \\
\text { of pleiotropy among these four traits. } \\
\text { However, the MD-AD results reflect } \\
\text { a mediated pleiotropy mechanism } \\
\text { (i.e., causal relationship) with an } \\
\text { effect of MD on AD, while there was } \\
\text { no evidence for reverse causation. }\end{array}$ & $\begin{array}{l}\text { The study supports a causal role for } \\
\text { genetic liability of MD on AD based } \\
\text { on genetic datasets including } \\
\text { thousands of individuals. }\end{array}$ & $\begin{array}{c}\text { Larger AD and MD datasets } \\
\text { will be required to confirm } \\
\text { the study findings using } \\
\text { genetic instruments based on } \\
\text { genetic } \\
\text { variants that reached the } \\
\text { more conservative } \\
\text { genome-wide significance } \\
\text { (i.e., } p<5 \times 10^{-8} \text { for a } \\
\text { particular SNP). }\end{array}$ \\
\hline $\begin{array}{l}\text { Martínez- } \\
\text { Magaña et al. } \\
2019 \text { [73] }\end{array}$ & $\begin{array}{l}192 \text { individuals of Mexican } \\
\text { Ancestry (125 cases and } 67 \\
\text { controls). } 72 \text { of the cases } \\
\text { had e lifetime DSM-IV } \\
\text { schizophrenia (SCZ), while } \\
53 \text { (m = 25) were with BPD } \\
\text { diagnosis. Of the latter, } 23 \\
\text { had AD or alcohol abuse } \\
\text { (in some combined with } \\
\text { other SUD-nicotine, } \\
\text { cocaine, cannabis, } \\
\text { inhalants, or stimulants). } \\
\text { Correlational testing of the } \\
\text { variance of dual diagnosis } \\
\text { (DD }{ }^{8} \text { ) phenotype } \\
\text { explained by } \\
\text { PGC-MDD1-PRS, } \\
\text { PGC-BD1-PRS, and } \\
\text { PGC-SCZ-PRS was } \\
\text { performed, i.e., the } \\
\text { hypothesis of whether the } \\
\text { current PRS might correlate } \\
\text { with a lifetime DD } \\
\text { was checked. }\end{array}$ & $\begin{array}{c}\text { PGC-MDD1-PRS showed a } \\
\text { significant shared genetic etiology } \\
\text { with the DD phenotype (Nagelkerke } \\
\text { Pseudo-R2 = 0.0451, corr. } p=0.0118 \text {, } \\
\mathrm{n}=334 \text { SNPs) whereas BPD-PRS did } \\
\text { not ( } p=0.1585 \text { ). Patients with DD in } \\
\text { the BD group had a higher } \\
\text { MDD-PRS when compared to } \\
\text { non-DD BD patients ( } p<0.05) \text {. } \\
\text { Notably, PGC-SZC-PRS [66] also } \\
\text { demonstrated statistically significant } \\
\text { common genetic background with } \\
\text { DD phenotype, including DD-BPD } \\
\text { (Pseudo-R2 = 0.0283, corr. } p=0.0118, \\
\mathrm{n}=8058 \text { SNPs), but it could not } \\
\text { discriminate statistically DD-BD } \\
\text { cases from non-DD-BD ones. } \\
\text { Besides, MDD-PRS explained a } \\
\text { higher amount of variance (4.51\%) } \\
\text { predicting placement in the DD } \\
\text { group (for both SCZ and BPD } \\
\text { patients) than did the } \\
\text { SCZ:PRS ( } 2.83 \% \text { ). }\end{array}$ & $\begin{array}{l}\text { The study results suggest that both } \\
\text { the MDD-PRS and the SCZ-PRS } \\
\text { might be useful in detecting DD risk. } \\
\text { However, when PRSs are applied to } \\
\text { a specific diagnosis, MDD-PRS used } \\
\text { in patients with BD is the only } \\
\text { specific PRS which discriminates DD } \\
\text { from non-DD cases. The shared } \\
\text { genetic susceptibility between MDD } \\
\text { and AD (or alcohol abuse) might } \\
\text { drive this result given the fact that } \\
\text { the main problem substance in the } \\
\text { studied sample was (apart from } \\
\text { nicotine) alcohol. }\end{array}$ & $\begin{array}{l}\text { The study is one of the first } \\
\text { approximations on how to } \\
\text { apply psychiatric PRS } \\
\text { in admixed populations (i.e., } \\
\text { with ancestry different from } \\
\text { European, } \\
\text { European-American, or } \\
\text { African-American). } \\
\text { The application of PRS in } \\
\text { different populations, } \\
\text { with distinct admixtures and } \\
\text { diverse phenotypes, } \\
\text { could give more information } \\
\text { on the use of PRS for } \\
\text { psychiatric disorders as a } \\
\text { translational risk prediction. } \\
\text { Limitations: small } \\
\text { sample size. }\end{array}$ \\
\hline
\end{tabular}


Table 1. Cont.

\begin{tabular}{|c|c|c|c|c|}
\hline Study & Sample & $\begin{array}{c}\text { Identified High-Risk } \\
\text { Polymorphisms/PRS Associations }\end{array}$ & Neurobiological Underpinnings & Comments \\
\hline $\begin{array}{l}\text { Colbert et al. } \\
2020[74]\end{array}$ & $\begin{array}{c}>900,000 \text { subjects (cases } \\
\text { and controls) from five } \\
\text { different GWAS samples } \\
\text { with anxiety disorders } \\
\text { [68,75], AD [70], problem } \\
\text { alcohol use (PAU) [76], and } \\
\text { alcohol consumption (AC) } \\
\text { [77] phenotypes. }\end{array}$ & $\begin{array}{l}\text { All anxiety phenotypes showed a } \\
\text { significant positive genetic } \\
\text { correlation with AUDIT- } p \text { (items of } \\
\text { AUDIT associated with problem } \\
\text { alcohol use) and AD ( } \mathrm{r}_{\mathrm{g}} \geq 0.35 \text { ). } \\
\text { However, the anxiety phenotypes } \\
\text { were uncorrelated with AUDIT-C } \\
\text { (part of AUDIT-related AC) and } \\
\text { drinks per week, indicating AC was } \\
\text { not genetically related to anxiety. } \\
\text { In females, three significant positive } \\
\text { genetic correlations were found } \\
\text { between PAU and anxiety } \\
\text { phenotypes DSM-V-like GAD }{ }^{9} \text { and } \\
\text { any anxiety disorder. No such } \\
\text { correlation was observed in males. } \\
47 \text { independent loci with significant } \\
\text { ( } p<7.60 \times 10^{-7} \text { ) local } \\
\text { genetic covariance between pairs of } \\
\text { traits were identified and three of } \\
\text { them showed positive local genetic } \\
\text { covariance between PAU and } \\
\text { anxiety phenotypes. }\end{array}$ & $\begin{array}{l}\text { One of the identified loci is at chr. } 11 \\
\text { (11:113 } 105405-113958177 \text { ) and it } \\
\text { contains the dopaminergic pathway } \\
\text { gene (DRD2) which substantially } \\
\text { moderates stress-induced alcohol } \\
\text { consumption in mice and also } \\
\text { influences connectivity between } \\
\text { basal ganglia and frontal cortices. } \\
\text { The region also contains NCAM } \\
\text { (Neural Cell Adhesion Molecule } \\
\text { gene), TTC12 (Tetratricopeptide } \\
\text { Repeat Domain } 12 \text { gene) and ANKK1 } \\
\text { (Ankyrin Repeat and Protein Kinase } \\
\text { Domain-Containing Protein } 1 \text { gene) } \\
\text { which, together with DRD2, form the } \\
\text { so-called NTAD gene suggestively } \\
\text { contributing to various psychiatric } \\
\text { disorders as well as the comorbidity } \\
\text { of psychiatric disorders. } \\
\text { A locus on chromosome } 9 \text { (10 } 879 \\
18811616822 \text { ), previously not } \\
\text { implicated in AUD, was also found } \\
\text { to have multiple significant positive } \\
\text { covariances between anxiety and } \\
\text { PAU, but not AC. } \\
\text { This locus has been previously } \\
\text { associated with worry and } \\
\text { neuroticism, depression, and anxiety } \\
\text { but has not been associated with } \\
\text { alcohol misuse anxiety comorbidity. }\end{array}$ & $\begin{array}{l}\text { Genetic covariance between } \\
\text { anxiety traits and PAU is } \\
\text { concentrated in certain brain } \\
\text { areas: amygdala, caudate } \\
\text { basal ganglia and } \\
\text { frontal cortex. } \\
\text { These results align findings } \\
\text { from fMRI studies pointing to } \\
\text { the role of these regions in } \\
\text { anxiety and alcohol use. } \\
\text { Limitations: GWAS sample } \\
\text { sizes are not large enough } \\
\text { given the small variations of } \\
\text { risk associated with } \\
\text { identified loci. } \\
\text { Limited panels for expression } \\
\text { is another limitation of } \\
\text { the study. } \\
\text { Finally, the analyses does not } \\
\text { identify specific mechanisms } \\
\text { which contribute to } \\
\text { the comorbidity } \\
\text { of the two disorders or a } \\
\text { causal direction. }\end{array}$ \\
\hline
\end{tabular}

\footnotetext{
${ }^{1}$ RDS = Research Diagnostic Criteria; ${ }^{2}$ EA = European-American; ${ }^{3}$ AA = African-American; ${ }^{4}$ ADHD = Attention Deficit Hyperactivity Disorder; ${ }^{5}$ BOLD fMRI = Blood Oxygen Level Dependent Functional Magnetic Resonance Imaging; ${ }^{6}$ MID = Monetary Incentive Delay;

${ }^{7}$ NIAAA $=$ National Institute on Alcohol Abuse and Alcoholism; ${ }^{8}$ DD $=$ Dual Diagnosis; ${ }^{9}$ GAD $=$ Generalized Anxiety Disorder.
}

\section{Discussion}

The present paper aims to summarize studies applying the genome-wide association approach in the search of shared genetic diathesis of mood and anxiety disorders with AUDs. GWAS have brought a massive advance in the understanding of genetic mechanisms that underlie mental disorders and the expansion of insight is being now gradually translated from "pure" diagnoses (i.e., schizophrenia, MDD, etc.) to comorbid phenotypes. In one of the first GWAS analyses of high-risk polymorphisms in BPD and SUD, Johnson et al. (2009) [78] established an overlap of the genetic diathesis for both groups of conditions compatible with the polygenic disorders model. Extracting data from several samples with BPD $(n=1461)$ and SUD $(n=400)$, these authors identified nominally significant SNPs in 69 high-risk genes that were common between the BPD samples and 23 of them were also associated with higher risk of SUD. Some of the spotted high-risk loci have been replicated by later studies included in this review-for instance, SNPs in the COLLA2 gene [46] found to be associated with BPD-AD phenotype, or CDH13 gene involved in the MDD-AD association according to Edwards et al. [49] study. In addition, genes belonging to gene families later found to be associated with AUD-mood disorders comorbidity were also identified in Johnson et al.'s pivotal study-for example semaphorins which are a group of transmembrane proteins engaged in axonal guidance during neural development. An SNP within the semaphorin 3A gene was confirmed in 2017 by Zhou et al. [63] to be involved in MDD-AD comorbidity.

It appears that the majority of significant risk-associated SNPs detected in samples with mood and anxiety disorders and co-occurring AUD are located in genome regions primarily engaged in the processes of neural growth, development, and differentiation as well as in the coding of neurotransmitter receptors and ion channels controlled by them. In this respect, a comparison of the results of GWAS with that of the first-generation genetic studies on alcoholism (linkage and candidate gene studies) which emphasize genes involved in alcohol metabolism-e.g., alcohol-dehydrogenase (ADH) gene cluster [79] or genes coding targets of alcohol pharmacodynamic activity-e.g., GABRA2 (GABA-A 
receptor subunit $\alpha$-2) [80] is very characteristic. Indeed, some of these early studies have correctly identified genes that were later found to markedly increase the risk of alcoholism being comorbid with mood or anxiety disorders. For example, the early candidate gene for alcoholism DRD2 (dopamine type 2 receptor) [81] was linked through several SNPs to state and trait levels of anxiety in a Korean sample of AD patients $(n=573)$ by Joe et al. in 2008 [82], only to be confirmed as a genome-wide significant locus for shared vulnerability to both alcoholism and BPD (Levey et al. 2014 [51] and anxiety disorder-problem alcohol use (Colbert et al. 2020 [74]). Interestingly, this same gene along with ANKK1 was recently confirmed by a meta-analysis of the three largest GWAS on depression as having a key role in MDD [83]. Such a finding supports the significant pleiotropic effects of genes underlying mental disorders and the multifunctional nature or neuronal circuits in which the products of these genes are involved.

Other genetic loci captured by first-generation studies have only shown their role in comorbidity by broadening of the initial phenotype. Thus, in the COGA study previously mentioned $[29,30]$, enriching the phenotype of interest from alcoholism only to alcoholism and ADHD, allowed for a recognition (by a Lod score > 3.0) of a locus on chromosome 2 harboring tachykinin receptor gene (TACR1). Subsequently, this gene which codes a receptor for the Substance P neurotransmitter and modulator peptide, involved in stress response and mood and anxiety regulation, has been confirmed as being implicated in BPDAD phenotype in the GWAS study of Sharp et al. (2014) [50]. It may be expected, therefore, that future GWAS employing broader phenotype definitions (e.g., BPD + ADHD + AUD), could identify yet other, previously unknown or considered alcoholism "specific" genes, as relevant to AUD-mood and/or anxiety disorder comorbidity.

It should be noted however that some promising genetic regions marked by recent genetic studies in comorbid AUD-mood disorder or AUD-anxiety disorder samples, have not been so far replicated by the genome-wide approach. In the MDD-AUD association for example, Procopio et al. (2013) [84] studied a sample of 333 AD women in Austria of which 51 had a combination of MDD and AD known as Type III alcoholism according to the classification of Lesch et al. [85]. The authors found a significant association of the MDD-alcoholism phenotype with haplotypes (i.e., SNPs) within ADCY5 (type 5 adenylyl cyclase protein gene) on chr. 3, ADCY2 (chr. 5), and ADCY8 (chr. 8) that could discriminate type III alcoholism patients from type I and II. The ADCY trans-membrane protein family is intimately related to the functioning of G-protein coupled receptors and is engaged in procedural learning, synaptic plasticity, and neurodegeneration. In addition to that, it has been linked to the vulnerability to alcohol dependence by previous GWAS studies. [86]. However, no study as yet has replicated ADCY protein family's relevance to the comorbid phenotype of AD and mood or anxiety disorder. Similarly, in the BPD-alcohol abuse phenotype Mosheva et al. (2019) [87] have recently reported a SNP (rs1034936) within the CACNA1C gene which codes the $\alpha 1$-subunit of the L-type voltage-gated calcium channel and has been implicated in various mental disorders (including MDD and BPD) but also in alcohol effects on CNS. However, not a single GWAS has identified it as directly contributing to BPD-AUD comorbidity so far. In the anxiety disorder(s)-AD phenotype, a recent study by Hodgson et al. (2016) [88] in a sample of 1284 Mexican-Americans from 75 pedigrees reported significant bivariate linkage peaks for alcohol dependenceanxiety at chromosome 9 (9q33.1-q33.2). In addition to hosting rare copy number variants (CNV) that have been linked to autistic spectrum disorders, ADHD, and OCD by a large GWAS [89], this locus also contains the astroactin-2 (ASTN2) and tri-component motif protein 32 (TRIM32). The former encodes the homonymous transmembrane protein, which along with related astroactin-1 (ASTN1) (1q25.2) has a key role in glial-directed neuronal migration during the embryonal formation of the neocortex [89] while the latter is engaged in functional control of dysbindin-a protein intimately involved in the genetics of schizophrenia [90] and influencing glutamate and dopamine signalization [91]. It remains to see whether future GWAS with AUD-anxiety disorders phenotypes will replicate the 
preliminary significant pleiotropic signals for alcohol dependence-anxiety found in 9q33.1q33.2 locus.

Further, in the context of causal theories of comorbidity mentioned above (22) it should be noted that some GWAS studies support a causal role of one of the associated disorders on the other. Thus, Polimanti et al. (2019) [71], analyzing large datasets of PGC-MDD-PRS2, PGC-AD-PRS, and UK-Biobank, found evidence for the causal influence of MDD on AD (i.e., mediated pleiotropy) but not the opposite. A possible neurobiological mechanism substantiating such a finding could be an inherited dysfunction of the DRD2 gene (discussed above) translated into lower activity of the D2 receptors resulting in anhedonia and compensatory drug or alcohol consumption. Similarly, in the background of anxiety disorders-alcoholism comorbidity, some of the available GWAS data support the occurrence of alcohol misuse in an attempt to alleviate anxiety compatible with the selfmedication hypothesis of comorbidity [92]. For instance, Colbert et al. (2020) in the study reviewed above observed a negative correlation between anxiety and alcohol consumption at chromosome 7:68 562 932-69 806895 which contains the AUTS2 (autism susceptibility candidate 2 gene). AUTS2, involved in activation of gene transcription as well as in neuronal migration during embryonal development, is an important candidate gene for autism spectrum and intellectual disability disorders; along with being expressed in amygdala and frontal cortex, it also influences alcohol consumption in humans [93]. Besides, its downregulation in Drosophila reduces sensitivity to alcohol, thus possibly increasing consumption [93], while in mice deficient in AUTS2, a decrease in anxiety-related behaviors is evident [94]. Hence, it may be speculated that AUTS2 not only affects anxiety and alcohol consumption in inverse directions, but, as a result of altered function, produces higher anxiety levels and subsequent alcohol misuse induced by the self-medication mechanism. Obviously, to validate or reject the hypothesis of mediated pleiotropy in mood and anxiety disorders comorbid with alcohol misuse, future studies with much larger and refined discovery and target samples will be needed.

Finally, several potential target genes and respective neural mechanisms contributing to comorbidity will be outlined. First in the list is glutamate neurotransmission with its probable role in dual diagnosis supported by recent GWAS implicating the glutamate receptor gene GRIA4 in nicotine dependence-MDD phenotype [95] as well as by the finding that alcohol exposure changes the expression of this and other glutamatergic genes [96]. Besides, impaired NMDA receptor functioning seen in BPD may contribute to the increased tolerance to alcohol resulting in alcohol misuse [97]. Another gene with a high likelihood of contributing to dual diagnosis phenotypes is the $\alpha$-endommanosidase gene MANEA which, despite its unclarified biological function, has variants found to increase anxiety disorder risk in samples recruited from genetic studies of alcohol and drug dependence [98]. Further in the line are genes participating in circadian clock function such as ARNT, ARNT2, and PER2 which have been implicated in anxiety disorders-alcohol dependence comorbidity $[99,100]$ and D-box binding protein gene (Dbp) supposedly influencing the risk for both bipolar disorder and alcoholism [101].

An inherent limitation of genome-wide association design pertinent to its applicability to co-occurring AUD, mood, and anxiety disorders is the inability to link identified high-risk polymorphisms with meaningful neurobiological pathways, thus paving the way for more successful treatment and prevention strategies. Another major restriction of the currently available GWAS focusing on comorbidity is that discovery samples used for identification of high-risk SNPs are of Western European and North-American ancestry only (see table) which substantially limits the generalization of findings across other populations, given that PRS are very sensitive to ethnic background [102]. This implies that variability in a PRS can be seriously affected by allele frequency differences, divergences in estimated effect sizes, and dissimilarities in population structure across various ethnic groups. For example, the $19 \mathrm{G} / \mathrm{C}$ (rs1800883) SNP in the serotonin 5A gene (5-HT5A) was found to have a protective role in relation to BPD risk in a British sample $(n=374)$ [103] whereas this same variant was significantly associated with BPD risk in a Bulgarian candidate gene study 
( $n=450)$ [104]. Furthermore, PRS usually measures only the contribution of common SNPs in an individual not accounting for other classes of variation which may also influence genetic risk. For instance, copy number variants known to exert a large impact on disease risk are not included in a typical PRS. For the same reason, rare pathogenic alleles are quite often eliminated from PRSs derived from a GWAS summary statistics, because GWASs by definition only include "common" variants with a population prevalence $\geq 1 \%$. Finally, as mentioned by some [49], the discovery samples from which MDD and BPD-PRS are extracted (like for example the PGC-MDD-PRS and PGC-BPD-PRS) might include a high number of alcohol or other substance-induced mood episode cases which significantly confounds the results of studies exploring shared genetic diathesis between alcohol use disorders and mood and anxiety disorders based on PRS.

\section{Conclusions}

In summary, GWAS exploring the genetic background of comorbid AUD, mood, and anxiety disorders demonstrate that multiple genetic variants with different directions and magnitudes influence the development, manifestation, and variation of these dual diagnosis phenotypes. Comorbidity risk is probably conveyed by genes engaged in neuronal development, connectivity, and signaling. It may therefore be hypothesized that comorbidity might represent an expression of a neurodevelopmental disruption that affects cortical and other areas involved in executive functioning, and emotional, and reward processing. In turn, that renders affected individuals susceptible to the occurrence of both mental disorder and SUD, including alcohol [22].

In addition to the intrinsic restriction of GWAS design, a significant barrier to eliciting the role of genetic variants involved in comorbidity is that they supposedly interact with one another (epistasis), may be involved in multiple phenotypes (pleiotropy), and are subject to complex epigenetic influences which are currently largely unknown.

Given that genes associated with complex traits including comorbid clinical presentations are of small effect, and are individually responsible for a very low proportion of total variance, larger samples consisting of multiple refined comorbid combinations and confirmed by re-sequencing approaches will be necessary to disentangle the genetic nature of dual diagnosis.

Author Contributions: Conceptualization, K.S.; methodology, K.S., D.D., E.N.; investigation, E.N., K.S.; data curation, K.S., D.D., Z.K.; writing—original draft preparation, K.S., E.N.; writing-review and editing, K.S., E.N., D.D., Z.K.; project administration, K.S.; All authors have read and agreed to the published version of the manuscript.

Funding: This research received no external funding.

Institutional Review Board Statement: Not applicable.

Informed Consent Statement: Not applicable.

Data Availability Statement: Not applicable.

Conflicts of Interest: The authors declare no conflict of interest.

\section{References}

1. Griswold, M.G.; Fullman, N.; Hawley, C.; Arian, N.; Zimsen, S.R.M.; Tymeson, H.D.; Venkateswaran, V.; Tapp, A.D.; Forouzanfar, M.H.; Salama, J.S.; et al. Alcohol use and burden for 195 countries and territories, 1990-2016: A systematic analysis for the global burden of disease study 2016. Lancet 2018, 392, 1015-1035. [CrossRef]

2. World Health Organization (WHO). Depression and Other Common Mental Disorders; WHO: Geneve, Switzerland, 2017.

3. Grant, B.F.; Stinson, F.S.; Dawson, D.A.; Chou, P.; Dufour, M.C.; Compton, W.; Pickenberg, R.F.; Kaplan, K. Prevalence and co-occurrence of substance use disorders and independent mood and anxiety disorders: Results from the national epidemiologic survey on alcohol and related conditions. Arch. Gen. Psychiatry 2004, 61, 807-816. [CrossRef]

4. Boschloo, L.; Vogelzangs, N.; Van den Brink, W.; Smit, J.; Veltman, D.; Beekman, A.T.; Pennix, B.W. Alcohol use disorders and the course of depressive and anxiety disorders. Br. J. Psychiatry 2012, 200, 476-484. [CrossRef]

5. Prior, K.; Mills, K.; Ross, J.; Teesson, M. Substance use disorders comorbid with mood and anxiety disorders in the Australian general population. Drug Alc. Rev. 2016, 36, 317-324. [CrossRef] 
6. Kessler, R.C.; Crum, R.M.; Warner, L.A.; Nelson, C.B.; Schulenberg, J.; Anthony, J.C. Lifetime co-occurrence of DSM-III-R alcohol abuse and dependence with other psychiatric disorders in the National Comorbidity Survey. Arch. Gen. Psychiatry 1997, 54, 313-321. [CrossRef]

7. Offord, D.R.; Boyle, M.H.; Campbell, D.; Goering, P.; Lin, E.; Wong, M.; Racine, Y.A. One-year prevalence of psychiatric disorder in Ontarians 15 to 64 years of age. Can. J. Psychiatry 1996, 41, 559-563. [CrossRef] [PubMed]

8. De Graaf, R.; Bijl, R.V.; Smit, F.; Vollebergh, W.A.; Spijker, J. Risk factors for 12-month comorbidity of mood, anxiety, and substance use disorders: Findings from the Netherlands Mental Health Survey and Incidence Study. Am. J. Psychiatry 2002, 159, 620-629. [CrossRef] [PubMed]

9. Hasin, D.S.; Stinson, F.S.; Ogburn, E.; Grant, B.F. Prevalence, correlates, disability, and comorbidity of DSM-IV alcohol abuse and dependence in the United States: Results from the National Epidemiologic Survey on Alcohol and Related Conditions. Arch. Gen. Psychiatry 2007, 64, 830-842. [CrossRef]

10. Conway, K.P.; Compton, W.; Stinson, F.S.; Grant, B.F. Lifetime comorbidity of DSM-IV mood and anxiety disorders and specific drug use disorders: Results from the National Epidemiologic Survey on Alcohol and Related Conditions. J. Clin. Psychiatry 2006, 67, 247-257. [CrossRef]

11. Kuria, M.W.; Ndetei, D.M.; Obot, I.S.; Khasakhala, L.I.; Bagaka, B.M.; Mbugua, M.N.; Kamau, J. The association between alcohol dependence and depression before and after treatment for alcohol dependence. ISRN Psychiatry 2012, 482802. [CrossRef]

12. Gabriels, C.M.; Macharia, M.; Weich, L. Psychiatric comorbidity among alcohol-dependent individuals seeking treatment at the Alcohol Rehabilitation Unit, Stikland Hospital. S. Afr. J. Psychiatr. 2019, 25, 1218. [CrossRef] [PubMed]

13. Cardose, B.M.; Sant'Anna, M..K.; Dias, V.D.; Andreazza, A.C.; Ceresér, K.M.; Kapczinski, F. The-impact of co-morbid alcohol use disorder in bipolar patients. Alcohol 2008, 42, 451-457. [CrossRef] [PubMed]

14. Schuckit, M.A.; Hesselbrock, V. Alcohol dependence and anxiety disorders: What is the relationship. Am. J. Psychiatry 1994, 151, 1723-1724. [CrossRef] [PubMed]

15. Lai, H.M.; Cleary, M.; Sitharthan, T.; Hunt, G.E. Prevalence of comorbid substance use, anxiety and mood disorders in epidemiological surveys, 1990-2014: A systematic review and meta-analysis. Drug Alcohol Depend. 2015, 154, 1-13. [CrossRef]

16. Burns, L.; Teesson, M. Alcohol use disorders comorbid with anxiety, depression and drug use disorders. Findings from the Australian National Survey of Mental Health and Well Being. Drug Alcohol Depend. 2002, 68, 299-307. [CrossRef]

17. Smith, J.P.; Randall, C.L. Anxiety and alcohol use disorders: Comorbidity and treatment considerations. Alcohol Res. 2012, 34, 414-431.

18. Davis, L.; Uezato, A.; Newell, J.M.; Frazier, E. Major depression and comorbid substance use disorders. Curr. Opin. Psychiatry 2008, 21, 14-18. [CrossRef] [PubMed]

19. Foulds, J.A.; Adamson, S.J.; Boden, J.M.; Williman, J.A.; Mulder, R.T. Depression in patients with alcohol use disorders: Systematic review and meta-analysis of outcomes for independent and substance-induced disorders. J. Affect. Disord 2015, 185, 47-59. [CrossRef]

20. Mueser, K.T.; Drake, R.E.; Wallach, M.A. Dual diagnosis: A review of etiological theories. Addict. Behav. 1998, 23, 717-734. [CrossRef]

21. Hintz, T.; Mann, K. Comorbidity in alcohol use disorders: Focus on mod, anxiety and personality. In Dual Diagnosis: The Evolving Conceptual Framework; Stohler, R., Rösler, W., Eds.; Karger: Basel, Switzerland, 2005; pp. 65-91.

22. Stoychev, K.R. Neuroimaging studies in patients with mental disorder and co-occurring substance use disorder: Summary of findings. Front. Psychiatry 2019, 10. [CrossRef]

23. Krueger, R.F. The structure of common mental disorders. Arch. Gen. Psychiatry 1999, 56, 921-926. [CrossRef] [PubMed]

24. Krueger, R.F.; McGue, M.; Iacono, W.G. The higher-order structure of common DSM mental disorders: Internalization, externalization, and their connections to personality. Personal. Individ. Differ. 2001, 30, 1245-1259. [CrossRef]

25. Kendler, K.S.; Prescott, C.A.; Myers, J.; Neale, M.C. The Structure of genetic and environmental risk factors for common psychiatric and substance use disorders in men and women. Arch. Gen. Psychiatry 2003, 60, 929-937. [CrossRef] [PubMed]

26. Tawa, E.A.; Hall, S.D.; Lohoff, F.W. Overview of the genetics of alcohol use disorder. Alcohol Alcohol. 2016, 51, 507-514. [CrossRef]

27. Lappalained, J. Genetic basis of dual diagnosis. In Dual Diagnosis and Psychiatric Treatment; Kranzler, J.R., Tinsley, J.A., Eds.; Marcel Dekker: New York, NY, USA, 2004.

28. Nurnberger, J.I., Jr.; Foroud, T.; Flury, L.; Su, J.; Meyer, E.T.; Hu, K.; Crowe, R.; Edenberg, H.; Goate, A.; Bierut, L.; et al. Evidence for a locus on chromosome 1 that influences vulnerability to alcoholism and affective disorder. Am. J. Psychiatry 2001, 158, 718-724. [CrossRef] [PubMed]

29. Reich, T.; Edenberg, H.J.; Goate, A.; Williams, J.T.; Rice, J.P.; Van Eerdewegh, P.; Foroud, T.; Hesselbrock, V.; Schuckit, M.A.; Bucholz, K.; et al. Genome-wide search for genes affecting the risk for alcohol dependence. Am. J. Med. Genet. 1998, 81, $207-215$. [CrossRef]

30. Foroud, T.; Edenberg, H.J.; Goate, A.; Rice, J.; Flury, L.; Koller, D.L.; Bierut, L.J.; Conneally, P.M.; Nurnberger, J.I.; Bucholz, K.K.; et al. Alcoholism susceptibility loci: Confirmation studies in a replicate sample and further mapping. Alcohol Clin. Exp. Res. 2000, 24, 933-945. [CrossRef]

31. Fullerton, J.; Cubin, M.; Tiwari, H.; Wang, C.; Bomhra, A.; Davidson, S.; Miller, S.; Fairburn, C.; Goodwin, G.; Neale, M.C.; et al. Linkage analysis of extremely discordant and concordant sibling pairs identifies quantitative-trait loci that influence variation in the human personality trait neuroticism. Am. J. Hum. Genet. 2003, 72, 879-890. [CrossRef] 
32. Gelernter, J.; Page, G.P.; Bonvicini, K.; Woods, S.W.; Pauls, D.L.; Kruger, S. A chromosome 14 risk locus for simple phobia: Results from a genomewide linkage scan. Mol. Psychiatry 2003, 8, 71-82. [CrossRef]

33. Nash, M.W.; Huezo-Diaz, P.; Williamson, R.J.; Sterne, A.; Purcell, S.; Hoda, F.; Cherny, S.S.; Abecasis, C.R.; Prince, M.; Gray, J.A.; et al. Genome-wide linkage analysis of a composite index of neuroticism and mood-related scales in extreme selected sibships. Hum. Mol. Genet. 2004, 13, 2173-2182. [CrossRef]

34. Donadon, M.F.; Osório, F.L. Personality traits and psychiatric comorbidities in alcohol dependence. Braz. J. Med. Biol. Res. 2016, 49. [CrossRef]

35. Duncan, L.E.; Ostacher, M.; Ballon, J. How genome-wide association studies (GWAS) made traditional candidate gene studies obsolete. Neuropsychopharmacol 2019, 44, 1518-1523. [CrossRef] [PubMed]

36. Burnbaum, R.; Weinberger, D.R. Pharmacological implications of emerging schizophrenia genetics. J. Clin. Psychopharmacol 2020, 40, 323-329. [CrossRef]

37. Klein, R.J.; Zeiss, C.; Chew, E.Y.; Tsai, J.Y.; Sackler, R.S.; Haynes, C.; Henning, A.K.; SanGiovanni, J.P.; Mane, S.M.; Bracken, M.B.; et al. Complement factor H polymorphism in age- related macular degeneration. Science 2005, 308, 385-389. [CrossRef] [PubMed]

38. Visscher, P.M.; Wray, N.R.; Zhang, Q.; Sklar, P.; McCarthy, M.I.; Brown, M.A.; Yang, J. 10 years of GWAS discovery: Biology, function, and translation. Am. J. Hum. Genet. 2017, 101, 5-22. [CrossRef]

39. Palk, A.C.; Dalvie, S.; de Vries, J.; Martin, A.R.; Stein, D.J. Potential use of clinical polygenic risk scores in psychiatry-ethical implications and communicating high polygenic risk. Philos. Ethics Humanit. Med. 2019, 14. [CrossRef]

40. Coleman, J.R.I.; Gaspar, H.A.; Bryois, J. The genetics of the mood disorder spectrum: Genome-wide association analyses of over 185,000 cases and 439,000 controls. Biol. Psychiatry 2020, 88, 168-184. [CrossRef]

41. Page, M.J.; McKenzie, J.E.; Bossuyt, P.M.; Boutron, I.; Hoffmann, T.C.; Mulrow, C.D.; Shamseer, L.; Terzlaf, J.M.; Alk, E.A.; Brennan, S.E.; et al. The PRISMA 2020 statement: An updated guideline for reporting systematic reviews. BMJ 2021, 372, n71. [CrossRef]

42. Saunders, J.B.; Aasland, O.G.; Babor, T.F.; de la Fuente, J.R.; Grant, M. Development of the alcohol use disorders identification test (AUDIT): WHO collaborative project on early detection of persons with harmful alcohol consumption-II. Addiction 1993, 88, 791-804. [CrossRef]

43. Ripke, S.; Wray, N.R.; Lewis, C.M.; Hamilton, S.P.; Weissman, M.M.; Breen, G.; Byrne, E.M.; Blackwood, D.H.R.; Boomsma, D.I.; Cichon, S.; et al. A mega-analysis of genome-wide association studies for major depressive disorder. Mol. Psychiatry 2013, 18, 497-511. [CrossRef]

44. Wray, N.R.; Ripke, S.; Mettheisen, M.; Trzaskowski, M.; Byrne, E.M.; Abdellaoui, A.; Adams, M.J.; Agerbo, E.; Air, T.M.; Andlauer, T.M.F.; et al. Genome-wide association analyses identify 44 risk variants and refine the genetic architecture of major depression. Nat. Genet. 2018, 50, 668-681. [CrossRef]

45. Sklar, P.; Ripke, S.; Scott, L.J.; Andreassen, O.A.; Cichon, S.; Craddock, N.; Edenberg, H.J., Jr.; Nurnberger, J.I.; Rietschel, M.; Blackwood, D.; et al. Large-scale genome-wide association analysis of bipolar disorder identifies a new susceptibility locus near ODZ4. Nat. Genet. 2011, 43, 977-983. [CrossRef]

46. Lydall, J.; Bass, N.J.; McQuillin, A.; Lawrence, J.; Anjorin, A.; Kandaswamy, R.; Pereira, A.; Guerrini, I.; Curtis, D.; Vine, A.E.; et al. Confirmation of prior evidence of genetic susceptibility to alcoholism in a genome-wide association study of comorbid alcoholism and bipolar disorder. Psychiatr. Genet. 2011, 21, 294-306. [CrossRef] [PubMed]

47. Johnson, C.; Drgon, T.; Liu, Q.R.; Walther, D.; Edenberg, H.; Rice, J.; Foroud, T.; Uhl, G.R. Pooled association genome scanning for alcohol dependence using 104268 SNPs: Validation and use to identify alcoholism vulnerability loci in unrelated individuals from the collaborative study on the genetics of alcoholism. Am. J. Med. Genet. B Neuropsychiatr. Genet. 2006, 141B, 844-853. [CrossRef] [PubMed]

48. Kerner, B.; Lambert, C.G.; Muthén, B.O. Genome-wide association study in bipolar patients stratified by co-morbidity. PLoS ONE 2011, 6, e28477. [CrossRef] [PubMed]

49. Edwards, A.C.; Aliev, F.; Bierut, L.J.; Bucholz, K.K.; Edenberg, H.; Hesselbrock, V.; Kramer, J.; Kuperman, S.; Nurnberger, J.I.; Schuckit, M.A.; et al. Genome-wide association study of comorbid depressive syndrome and alcohol dependence. Psychiatr. Genet. 2012, 22, 31-41. [CrossRef] [PubMed]

50. Sharp, S.I.; McQuillin, A.; Marks, M.; Hunt, S.P.; Stanford, S.C.; Lydall, G.J.; Morgan, M.Y.; Asherson, P.; Curtis, D.; Gurling, H.M.D. Genetic association of the Tachykinin Receptor 1 TACR1 gene in bipolar disorder, attention deficit hyperactivity disorder and the alcohol dependence syndrome. Am. J. Med. Genet.Part B Neuropsychiatr. Genet. 2014, 165B, 373-380. [CrossRef]

51. Levey, D.F.; Le-Niculescu, H.; Frank, J.; Ayalew, M.; Jain, N.; Kirlin, B.; Learman, R.; Winiger, E.; Rodd, Z.; Shekhar, A.; et al. Genetic risk prediction and neurobiological understanding of alcoholism. Transl. Psychiatry 2014, 4, e391. [CrossRef]

52. Treutlein, J.; Cichon, S.; Ridinger, M.; Wodarz, N.; Soyka, M.; Zill, P.; Maier, W.; Moessner, R.; Gaebel, W.; Dahmen, N.; et al. Genome-wide association study of alcohol dependence. Arch. Gen. Psychiatry 2009, 66, 773-784. [CrossRef]

53. Frank, J.; Cichon, S.; Treutlein, J.; Ridinger, M.; Mattheisen, M.; Hoffmann, P.; Herms, S.; Wodarz, N.; Soyka, M.; Zill, P.; et al. Genome-wide significant association between alcohol dependence and a variant in the ADH gene cluster. Addict. Biol 2012, 17, 171-180. [CrossRef]

54. Patel, S.D.; Le-Niculescu, H.; Koller, D.L.; Green, S.D.; Lahiri, D.K.; McMahon, F.J.; Nurnberger, J.I., Jr.; Niculescu, A.B., III. Coming to grips with complex disorders: Genetic risk prediction in bipolar disorder using panels of genes identified through convergent functional genomics. Am. J. Med. Genet. 2010, 153B, 850-877. [CrossRef] [PubMed] 
55. Le-Niculescu, H.; Case, N.J.; Hulvershorn, L.; Patel, S.D.; Bowker, D.; Gupta, J.; Bell, R.; Edenberg, H.J.; Tsuang, M.T.; Kuczenski, R.; et al. Convergent functional genomic studies of omega-3 fatty acids in stress reactivity, bipolar disorder and alcoholism. Transl. Psychiatry 2011, 1, e4. [CrossRef]

56. Carey, C.E.; Agrawal, A.; Bucholz, K.K.; Hartz, S.M.; Lynskey, M.T.; Nelson, E.C.; Bierut, L.J.; Bogdan, R. Associations between polygenic risk for psychiatric disorders and substance involvement. Front. Genet. 2016, 7, 149. [CrossRef]

57. Bierut, L.J.; Agrawal, A.; Bucholz, K.K.; Doheny, K.F.; Laurie, C.; Pugh, E.; Fisher, S.; Fox, L.; Howells, L.; Bertelsen, S.; et al. A genome-wide association study of alcohol dependence. Proc. Natl. Acad. Sci. USA 2010, 107, 5082-5087. [CrossRef]

58. Bierut, L.J.; Madden, P.A.; Breslau, N.; Johnson, E.O.; Hatsukami, D.; Pomerleau, O.F.; Swan, G.E.; Rutter, J.; Bertelsen, S.; Fox, L.; et al. Novel genes identified in a high-density genome wide association study for nicotine dependence. Hum. Mol. Genet. 2007, 16, 24-35. [CrossRef] [PubMed]

59. Bierut, L.J.; Strickland, J.R.; Thompson, J.R.; Afful, S.E.; Cottler, L.B. Drug use and dependence in cocaine dependent subjects, community-based individuals, and their siblings. Drug Alcohol Depend. 2008, 95, 14-22. [CrossRef]

60. Andersen, A.M.; Pietrzak, R.H.; Kranzler, H.R.; Ma, L.; Zhou, H.; Liu, X.; Kramer, J.; Kuperman, S.; Edenberg, H.J.; Rice, J.O.; et al. Polygenic scores for major depressive disorder and risk of alcohol dependence. JAMA Psychiatry 2017, 74, 1153-1160. [CrossRef]

61. Gelernter, J.; Sherva, R.; Koesterer, R.; Almasy, L.; Zhao, H.; Kranzler, H.R.; Farrer, L. Genome-wide association study of cocaine dependence and related traits: FAM53B identified as a risk gene. Mol. Psychiatry 2014, 19, 717-723. [CrossRef] [PubMed]

62. Fuehrlein, B.S.; Mota, N.; Arias, A.J.; Trevisan, L.A.; Kachadouran, L.K.; Krystal, J.H.; Southwick, S.M.; Pietrzak, T.H. The burden of alcohol use disorders in US military veterans: Results from the National Health and Resilience in Veterans Study. Addiction 2016, 111, 1786-1794. [CrossRef] [PubMed]

63. Zhou, H.; Polimanti, R.; Yang, B.; Wang, Q.; Shizhong, H.; Sherva, R.; Nuñez, Y.Z.; Zhao, H.; Farrer, L.A.; Kranzler, H.R.; et al. Genetic risk variants associated with comorbid alcohol dependence and major depression. JAMA Psychiatry 2017, 74, 1234-1241. [CrossRef]

64. Okbay, A.; Baselmans, B.; De Neve, J.E.; Turley, P.; Nivard, M.G.; Fontana, M.A.; Meddens, F.W.; Linner, R.K.; Rietveld, C.A.; Derringer, J.; et al. Genetic variants associated with subjective well-being, depressive symptoms, and neuroticism identified through genome-wide analyses. Nat. Genet. 2016, 48, 624-633. [CrossRef]

65. Reginsson, G.R.; Inganson, A.; Euesden, J.; Bjornsdottir, G.; Olafsson, S.; Sigurdson, E.; Oskarsson, H.; Tyrfingsson, T.; Runarsodottir, V.; Hansdottir, I.; et al. Polygenic risk scores for schizophrenia and bipolar disorder associate with addiction. Addict. Biol. 2018, 23, 485-492. [CrossRef] [PubMed]

66. Schizophrenia Working Group of the Psychiatric Genomics Consortium. Biological insights from 108 schizophrenia-associated genetic loci. Nature 2014, 511, 421-427. [CrossRef] [PubMed]

67. Muench, C.; Schwandt, M.; Jung, J.; Cortes, C.R.; Momenan, R.; Lohoff, F.W. The major depressive disorder GWAS-supported variant rs10514299 in TMEM161B-MEF2C predicts putamen activation during reward processing in alcohol dependence. Transl. Psychiatry 2018, 8, 131. [CrossRef] [PubMed]

68. Otowa, T.; Hek, K.; Lee, M.; Byrne, E.M.; Mirza, S.S.; Nivard, M.G.; Bigdeli, T.; Aggen, S.H.; Adkins, D.; Wolen, A.; et al. Metaanalysis of genome-wide association studies of anxiety disorders. Mol. Psychiatry 2016, 21, 1391-1399. [CrossRef] [PubMed]

69. Foo, J.C.; Streit, F.; Treutlein, J.; Ripke, S.; Witt, S.H.; Strohmaier, J.; Degenhardt, F.; Forstner, A.J.; Hoffmann, P.; Soyka, M.; et al. Shared genetic etiology between alcohol dependence and major depressive disorder. Psychiatr. Genet. 2018, 28, 66-70. [CrossRef] [PubMed]

70. Walters, R.K.; Polimanti, R.; Johnson, E.C.; McClintick, J.N.; Adams, M.J.; Adkins, A.E.; Aliev, F.; Bacanu, S.A.; Batzler, A.; Bertelsen, S.; et al. Transancestral GWAS of alcohol dependence reveals common genetic underpinnings with psychiatric disorders. Nat. Neurosci. 2018, 21, 1656-1669. [CrossRef] [PubMed]

71. Polimanti, R.; Peterson, R.E.; Ong, J.S.; MacGregor, S.; Edwards, A.; Clarke, T.K.; Frank, J.; Gerring, Z.; Gillespie, N.A.; Lind, P.A.; et al. Evidence of causal effect of major depression on alcohol dependence: Findings from the psychiatric genomics consortium. Psychol. Med. 2019, 49, 1218-1226. [CrossRef]

72. Allen, N.; Sudlow, C.; Downey, P.; Peakman, T.; Danesh, J.; Elliott, P.; Callacher, J.; Green, J.; Matthews, P.; Pell, J.; et al. UK Biobank: Current status and what it means for epidemiology. Health Policy Technol. 2012, 1, 123-126. [CrossRef]

73. Martínez-Magaña, J.J.; Gonzalez-Castro, T.B.; Genís-Mendoza, A.D.; Tovilla-Zárate, C.A.; Juárez-Rojop, I.E.; Saucedo-Uribe, E.; Rodriguez-Mayoral, O.; Lanzagorta, N.; Escamilla, M.; Macías-Kauffer, L.; et al. Exploratory analysis of polygenic risk scores for psychiatric disorders: Applied to dual diagnosis. Rev. Invest. Clin. 2019, 71, 321-329. [CrossRef]

74. Colbert, S.M.C.; Funkhouser, S.A.; Johnson, E.C.; Hoeffer, C.; Ehringer, M.A.; Evans, L.M. Differential shared genetic influences on anxiety with problematic alcohol use compared to alcohol consumption. MedRxiv 2020. [CrossRef]

75. Purves, K.L.; Coleman, J.R.I.; Meier, S.M.; Rayner, C.; Davis, K.A.S.; Cheesman, R.; Bækvad-Hansen, M.; Børglum, A.D.; Cho, S.W.; Deckert, J.J.; et al. A major role for common genetic variation in anxiety disorders. Mol. Psychiatry 2020, 25, 3292-3303. [CrossRef]

76. Sanchez-Roige, S.; Palmer, A.A.; Fontanillas, P.; Elson, S.L.; Adams, M.J.; Howard, D.M.; Mclntosh, A.M.; Clarke, T.K. Genomewide association study meta-analysis of the alcohol use disorders identification test (AUDIT) in two population-based cohorts. Am. J. Psychiatry 2019, 176, 107-118. [CrossRef]

77. Liu, M.; Jiang, Y.; Wedow, R.; Li, Y.; Brazel, D.M.; Chen, F.; Vrieze, S. Association studies of up to 1.2 million individuals yield new insights into the genetic etiology of tobacco and alcohol use. Nat. Genet. 2019, 51, 237-244. [CrossRef] 
78. Johnson, C.; Drgon, T.; McMahon, F.J.; Uhl, G.R. Convergent genome wide association results for bipolar disorder and substance dependence. Am. J. Med. Genet. Part B Neuropsychiatr. Genet. 2009, 150B, 182-190. [CrossRef]

79. Edenberg, H.J.; Xuei, X.; Chen, H.; Tian, H.; Wetherill, L.F.; Dick, D.M.; Almasy, L.; Bierut, L.; Bucholz, K.K.; Goate, A.; et al. Association of alcohol dehydrogenase genes with alcohol dependence: A comprehensive analysis. Hum. Mol. Genet. 2006, 15, 1539-1549. [CrossRef]

80. Enoch, M.A.; Hodgkinson, C.A.; Yuan, Q.; Shen, P.H.; Goldman, D.; Roy, A. The influence of GABRA2, childhood trauma, and their interaction on alcohol, heroin, and cocaine dependence. Biol. Psychiatry 2010, 67, 20-27. [CrossRef]

81. Cook, C.; Gurling, H. The D2 dopamine receptor gene and alcoholism: A genetic effect on the liability of alcoholism. J. R. Soc. Med. 1994, 87, 400-402. [PubMed]

82. Joe, K.H.; Kim, D.J.; Park, B.L.; Yoon, S.; Lee, H.K.; Kim, T.S.; Cheon, Y.H.; Gwon, D.H.; Cho, S.N.; Lee, H.W.; et al. Genetic association of DRD2 polymorphisms with anxiety scores among alcohol-dependent patients. Biochem. Biophys. Res. Commun. 2008, 371, 591-595. [CrossRef]

83. Howard, D.M.; Adams, M.J.; Clarke, T.K.; Hafferty, J.D.; Gibson, J.; Shiali, M.; McIntosh, A.M. Genome-wide meta-analysis of depression identifies 102 independent variants and highlights the importance of the prefrontal brain regions. Nat. Neurosci 2019, 22, 343-352. [CrossRef] [PubMed]

84. Procopio, D.O.; Saba, L.M.; Walter, H.; Lesch, O.; Skala, K.; Schlaff, G.; Tabakoff, B. Genetic markers of comorbid depression and alcoholism in women. Alcohol Clin. Exp. Res. 2013, 37, 896-904. [CrossRef] [PubMed]

85. Lesch, O.M.; Walter, H. Subtypes of alcoholism and their role in therapy. Alcohol Alcohol Suppl 1996, 31, 63-67. [CrossRef]

86. Edenberg, H.D.; Koller, D.L.; Xiaoling, X.; Wetherill, L.; McClintick, J.N.; Almasy, L.; Bierut, L.J.; Bucholz, K.K.; Goate, A.; Aliev, F.; et al. Genome-wide association study of alcohol dependence implicates a region on chromosome 11. Alcohol Clin. Exp. Res. 2010, 34, 840-852. [CrossRef]

87. Mosheva, M.; Serretti, A.; Stukalin, Y.; Fabbri, C.; Hagin, M.; Horev, S.; Mantovani, V.; Bin, S.; Matticcio, A.; Nivoli, A.; et al. Association between CANCA1C Gene rs1034936 polymorphism and alcohol dependence in bipolar disorder. J. Affect. Disord. 2019, 261, 181-186. [CrossRef] [PubMed]

88. Hodgson, K.; Almasy, L.; Knowles, E.E.M.; Kent, J.W.; Curran, J.E.; Dyer, T.D.; Göring, H.H.H.; Olvera, R.L.; Fox, P.T.; Pearlson, G.D.; et al. Genome-wide significant loci for addiction and anxiety. Eur. Psychiatry 2016, 36, 47-54. [CrossRef]

89. Lionel, A.C.; Tammimies, K.; Vaags, A.K.; Rosenfeld, J.A.; Ahn, J.W.; Merico, D.; Noor, A.; Runke, C.K.; Pillalamirri, V.K.; Carter, M.T.; et al. Disruption of the ASTN2/TRIM32 locus at 9q33.1 is a risk factor in males for autism spectrum disorders, ADHD and other neurodevelopmental phenotypes. Hum. Mol. Genet. 2014, 23, 2752-2768. [CrossRef]

90. Locke, M.; Tinsley, C.L.; Benson, M.A.; Blake, D.J. TRIM32 is an E3 ubiquitin ligase for dysbindin. Hum. Mol. Genet. 2009, 18, 2344-2358. [CrossRef]

91. Papaleo, F.; Weinberger, D.R. Dysbindin and schizophrenia: It's dopamine and glutamate all over again. Biol. Psychiatry 2011, 69, 2-4. [CrossRef] [PubMed]

92. Khantzian, E.J. The self-medication hypothesis of addictive disorders. Am. J. Psychiatry 1985, 142, 1959-1964. [CrossRef]

93. Schumann, G.; Coin, L.J.; Lourdusamy, A.; Charoen, P.; Berger, K.H.; Stacey, D.; Desrivières, S.; Aliev, F.; Khan, A.A.; Amin, N.; et al. Genome-wide association and genetic functional studies identidy autism susceptibility candidate 2 gene (AUTS2) in the regulation of alcohol consumption. Proc. Natl. Acad. Sci. USA 2011, 108, 7119-7124. [CrossRef]

94. Hori, K.; Nagai, T.; Shan, W.; Sakamoto, A.; Abe, M.; Yamazaki, M.; Sakimura, K.; Yamada, K.; Hoshini, M. Heterozygous disruption of autism susceptibility candidate 2 causes impaired emotional control and cognitive memory. PLOS ONE 2015, 10, e0145979. [CrossRef]

95. Zhou, H.; Cheng, Z.; Bass, N.; Krystal, J.H.; Farrer, A.; Kranzler, H.R.; Gelernter, J. Genome-wide association study identifies glutamate ionotropic receptor GRIA4 as a risk gene for comorbid nicotine dependence and major depression. Transl. Psychiatry 2018, 8. [CrossRef] [PubMed]

96. Enoch, M.A.; Rosser, A.A.; Zhou, Z.; Mash, D.C.; Yuan, Q.; Goldman, D. Expression of glutamatergic genes in healthy humans across 16 brain regions; altered expression in the hippocampus after chronic exposure to alcohol or cocaine. Genes Brain Behav. 2014, 13, 758-768. [CrossRef]

97. Di Nicola, M.; Moccia, L.; Ferri, V.L.; Panaccione, I.; Janiri, L. Alcoholism in bipolar disorder: An overview of epidemiology, common pathogenic pathways, course of disease, and implications for treatment. In Neuroscience of Alcohol; Preedy, V.R., Ed.; Academic Press: London, UK, 2019; pp. 363-371. [CrossRef]

98. Jensen, K.P.; Stein, M.B.; Kranzler, H.R.; Yang, B.Z.; Farrer, L.A.; Gelernter, J. The $\alpha$-endommanosidase gene (MANEA) is associated with panic disorder and social anxiety disorder. Transl. Psychiatry 2014, 4. [CrossRef] [PubMed]

99. Sipilä, T.; Kananen, L.; Greco, D.; Donner, J.; Silander, K.; Terwilliger, J.D.; Auvinen, P.; Peltonen, L.; Lönnqvist, J.; Pirkola, S.; et al. An association analysis of circadian genes in anxiety disorders. Biol. Psychiatry 2010, 67, 1163-1170. [CrossRef]

100. Spanagel, R.; Pendyala, G.; Abarca, C.; Zghoul, T.; Sanchis-Segura, C.; Magnone, M.C.; Lascorz, J.; Depner, M.; Holzberg, D.; Soyka, M.; et al. The clock gene Per2 influences the glutamatergic system and modulates alcohol consumption. Nat. Med. 2005, 11, 11-35. [CrossRef]

101. Le-Niculescu, H.; McFarland, M.J.; Ogden, C.A.; Balaraman, Y.; Patel, S.; Tan, J.; Rodd, Z.A.; Paulus, M.; Geyer, M.A.; Edenberg, H.J.; et al. Phenomic, convergent functional genomic, and biomarker studies in a stress-reactive genetic animal model of bipolar disorder and co-morbid alcoholism. Am. J. Med. Genet. B Neuropsychiatr Genet. 2008, 147B, 134-166. [CrossRef] 
102. Fullerton, J.M.; Nurnberger, J.L. Polygenic risk scores in psychiatry: Will they be useful for clinicians? F1000Research 2019, 8, F1000 Faculty Rev-1293. [CrossRef]

103. Birkett, J.T.; Arranz, M.J.; Munro, J.; Osbourn, S.; Kerwin, R.W.; Collier, D.A. Association analysis of the 5-HT5A gene in depression, psychosis and antipsychotic response. Neuro Rep. 2000, 11, 2017-2020. [CrossRef] [PubMed]

104. Yosifova, A.; Mushiroda, T.; Stoianov, D.; Vazharova, R.; Dimova, I.; Karachanak, S.; Zaharieva, I.; Milanova, V.; Madjirova, N.; Gerdjikov, I.; et al. Case-control association study of 65 candidate genes revealed a possible association of a SNP of HTR5A to be a factor susceptible to bipolar disease in Bulgarian population. J. Affect. Disord. 2009, 117, 87-97. [CrossRef] 